DISINFORMATION AND DIGITAL MEDIA AS A CHALLENGE FOR DEMOCRACY 


\section{European Integration and Democracy Series}

Editors-in-Chief

ELŻBIETA KUŻELEWSKA, University of Białystok, Poland

DARIUSZ KLOZA, Vrije Universiteit Brussel, Belgium

Managing Editor

IOULIA KONSTANTINOU, Vrije Universiteit Brussel, Belgium

Series Editors

DANIEL BARNHIZER, Michigan State University, East Lansing MI, United States of America

TOMAS BERKMANAS, Vytautas Magnus University, Kaunas, Lithuania FILIP Ǩ̌EPELKA, Masaryk University, Brno, Czech Republic ERICH SCHWEIGHOFER, University of Vienna, Austria RYSZARD SKARZYŃSKI, University of Białystok, Poland KONSTANTY A. WOJTASZCZYK, University of Warsaw, Poland 


\title{
DISINFORMATION AND DIGITAL MEDIA AS A CHALLENGE FOR DEMOCRACY
}

\author{
Edited by \\ Georgios Terzis \\ Dariusz KlozA \\ Elżbieta KużELEWSKA \\ Daniel Trottier \\ Managing Editor \\ Ioulia Konstantinou
}

\section{- intersentia}

Cambridge - Antwerp - Chicago 
Intersentia Ltd

8 Wellington Mews

Wellington Street | Cambridge

CB1 1HW | United Kingdom

Tel: +441223736170

Email: mail@intersentia.co.uk

www.intersentia.com | www.intersentia.co.uk

Distribution for the UK and

Rest of the World (incl. Eastern Europe)

NBN International

1 Deltic Avenue, Rooksley

Milton Keynes MK13 8LD

United Kingdom

Tel: +441752202301 | Fax: +44 1752202331

Email: orders@nbninternational.com

Distribution for Europe

Intersentia Publishing nv

Groenstraat 31

2640 Mortsel

Belgium

Tel: +32 36801550

Email: mail@intersentia.be

Distribution for the USA and Canada

Independent Publishers Group

Order Department

814 North Franklin Street

Chicago, IL 60610

USA

Tel: +1 8008884741 (toll free) | Fax: +1 3123375985

Email: orders@ipgbook.com

Disinformation and Digital Media as a Challenge for Democracy

(C) The editors and contributors severally 2020

The editors and contributors have asserted the right under the Copyright, Designs and Patents Act 1988, to be identified as authors of this work.

No part of this book may be reproduced, stored in a retrieval system, or transmitted, in any form, or by any means, without prior written permission from Intersentia, or as expressly permitted by law or under the terms agreed with the appropriate reprographic rights organisation. Enquiries concerning reproduction which may not be covered by the above should be addressed to Intersentia at the address above.

Artwork on cover: ๑ Opper, Frederick Burr, 1857-1937, The fin de siècle newspaper proprietor, Library of Congress Prints and Photographs Division Washington, D.C.

ISBN 978-1-78068-975-3

D/2020/7849/49

NUR 820

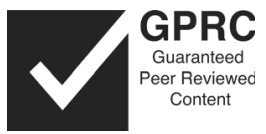

British Library Cataloguing in Publication Data. A catalogue record for this book is available from the British Library. 


\title{
FOREWORD
}

\section{Fooling All of the People All of the Time: Democracy in the Age of Fake News}

\author{
Jamie SHEA
}

George Orwell's statue stands outside BBC Broadcasting House in central London. His presence serves to remind this news organisation to have no fear of government or seek any favour in reporting accurately and fairly on the news of the day. Orwell's Nineteen Eighty-Four is the classic text on the role of propaganda and the distortion of language in reshaping reality. He famously said: 'if liberty means anything at all, it means the right to tell people what they do not want to hear.' Yet Orwell associated the world of 'two and two made five ${ }^{2}$ with the totalitarian powers of the 1930s and 1940s. They had the Big Brother dictators who could control all the instruments of public messaging and the ability to screen out alternative sources of information that made an alternative reality possible. The first step towards taking away individual freedom and the capacity for independent action is to deprive people of their access to factual information. This was the hallmark of the communist states that sprang up in Eastern Europe during the Cold War years. As the Czech playwright, dissident and later president Vaclav Havel put it, largely echoing Orwell: 'if the main pillar of the system is living a lie, then it is not surprising that the fundamental threat to it is living in truth. ${ }^{3}$

When the Berlin Wall came down 30 years ago, the change was largely attributed not to Western military pressure on the Soviet Union and its satellite states, but to the ultimate ability of the West to penetrate the Eastern firewall with its own news and information. The Germans from the East watched West German television and broadcasters such as the BBC World Service, Voice of

\footnotetext{
* Brussels School of Governance (BSG) (an alliance between the Institute for European Studies and Vesalius College), Vrije Universiteit Brussel (VUB), Belgium. Email: dr.jamiepshea@ gmail.com.

1 G. Orwell, 'The Freedom of the Press', The Times Literary Supplement, 15 September 1972, p. 1.

2 G. Orwell, Nineteen Eighty-Four, Secker \& Warburg, London 1949, p. 69.

3 V. Havel, The Power of the Powerless: Citizens against the State in Central Eastern Europe, translated by J. KeAne, Sharpe, Armonk, NY 1985, p. 40.
} 
America and Radio Free Europe managed to reach large audiences despite the best efforts of the local regimes to jam them. The leader of Solidarity in Poland, Lech Wałęsa, attributed the success of this movement to the Catholic Church and Radio Free Europe. It is worth recalling this time 30 years later because it underlines, along with Orwell and Havel, that the best instrument of democracies in their quest to build a more cooperative and peaceful international order is their ability to be governed by the truth. This stems from open public debates that allow citizens to come to their judgements based on free debate and a lively, unconstrained news media that is willing and able to hold public figures to account. As former US Senator Daniel Patrick Moynihan famously put it: 'you are entitled to your own opinion, but you are not entitled to your own facts. ${ }^{4}$

In order for democracy to function properly, there has to be a shared and agreed baseline of truth. If people divide into ideological bubbles and virtual reality ghettoes, believing only what they want to believe or are intellectually capable of believing, politics ceases to be an exercise of mutual persuasion and tolerance, and descends into a process of endless partisan manipulation and polarisation. It can reach a stage where information warfare prevents communities and countries from taking rational decisions and moving forward. At a time of mounting complexity, people retreat into simplistic and allembracing conspiracy theories that remove the need for compromise or serious intellectual effort. Rather than inconvenient facts and intractable realities, the non-believer becomes the enemy to be denigrated. Society splits up into hostile tribes glaring at each other across their information firewalls. As every fact or version of events is instantly contested and every event is surrounded by scores of different explanations, society distances itself further from what Voltaire is believed to have defined as the essence of democracy when he said that he disagreed profoundly with someone, but would be willing to die to defend their right to say it. ${ }^{5}$

Instead, we now have the motto of the Russian state RT channel which calls on us to 'Question More' and accept that every official version of events put out by our own governments hides more truth than it reveals. If, as RT proclaims, it is being unfairly victimised because there is 'always another side of the story', ${ }^{6}$ which it undertakes to reveal, then the view of the other person is not something to be respected and taken seriously, as Voltaire would have wished, but to be mistrusted and discounted. As Putin's numerous explanations for the shooting

4 Quoted in T.J. Penny, 'Facts are Facts', National Review, 4 September 2003, https://www. nationalreview.com/2003/09/facts-are-facts-timothy-j-penny.

5 Quoted in E.B. Hall, The Friends of Voltaire, Smith, London 1906, p. 199.

6 E. Peltier, 'Is France the Latest Front in Russia's Information War?', New York Times, 20 December 2017, https://www.nytimes.com/2017/12/19/world/europe/rt-france-television. html, p. 8. 
down of the Malaysian Airlines flight over Ukraine in July 2014 demonstrate, multiple versions of the 'truth' do not establish a credible alternative version, but cast enough doubt on the most likely interpretation as to give free rein to all sorts of conspiracy theories - and allow Russia to hide behind the cloak of endless deniability. This is facilitated by a social media culture that enables the rapid and widespread distribution of these alternative realities, something we have come to call fake news. Like most fakes, fake news has a glitz and a drama that prosaic reality finds difficult to emulate. It does not have to be true to be newsworthy and shareable. According to recent research by the Massachusetts Institute of Technology, fake news stories move around the Internet and social media at six times the speed of accurate reporting. ${ }^{7}$ As governments and media in democracies need to spend more and more time debunking conspiracy theories, they have less time to promote their own version of events. If truth is always relative or politically biased in favour of one side over another, why undertake the effort to discover it in the first place? Truth is what I want it to be.

How have the Western democracies squandered in the space of just a few decades since the end of the Cold War their most important asset in winning it: the capacity to identify and to set policy by the truth? How is it that the tables have been turned and the autocracies and authoritarians of this world now exploit information and human connectivity to undermine our system rather than us undermining theirs? If they are successful, it is not because they are the masters of spin and disinformation, but because they are able to exploit the weaknesses in our own way of receiving and handling information, and our own waning interest and commitment to truth in our politics and individual behaviour.

In the first place, the Internet and social media have made the act of communicating more important than the content of communication. Descartes once said 'I think, therefore I am, ${ }^{8}$ but today this might be better rendered as 'I communicate, therefore I am'. The Internet and social media isolate us from our fellow human beings, as we spend hours looking at screens, but also force us to be in constant contact with more and more of them. Expressing opinions and sharing tweets and posts is the price of joining the global conversation and having a sense of self-worth, even identity. The pressure to conform to the prevailing trend is intense if we are not to be left behind. So, paradoxically, the Internet and social media, which were designed to allow the expression of individual views and preferences, end up shaping a conformist mass opinion. At the same time, the Internet has allowed everyone to communicate and be

S. Vosoughi, D. Roy and S. Aral, 'The Spread of True and False News Online' (2018) 259(6380) Science 1146-1151, doi: 10.1126/science.aap9559.

8 R. Descartes, Discours de la méthode, Paris 1637. 
an influencer without needing to become famous and prominent, or gaining a voice through the traditional media. The American sociologist Clay Shirkey has expressed this well in the title of his book Here Comes Everybody. ${ }^{9}$ Some may see this mass participation in social and political communication as a liberating act of direct democracy and individual empowerment. Yet it also brings to the fore the darker side of humanity in the form of hatred, vitriol, bigotry and the ability to say outrageous things without the constraint of attribution and accountability. Bigots seeing their own views expressed by others believe that they are now legitimate and lose their own inhibitions about speaking out. In this way, the Internet, which began in the 1980s as the exemplar of free speech beyond government control and censorship, has become the massive purveyor of fake news. State propaganda and disinformation, radicalisation and indoctrination and state monitoring and control - so much so that recently Foreign Affairs magazine published an article by Richard Clarke and Rob Knake, former senior US officials, calling on democracies to set up a new Internet with stringent participation standards, because they believe the current global Internet has become irredeemably contaminated with trolls, automated bots, misinformation and disinformation, made-up hashtag campaigns and proxies pretending to be someone else. ${ }^{10}$

If the Internet and social media were merely being used to spread messages of peace and cooperation or to make money from the ubiquitous advertisements based on 'hit' statistics, perhaps we could live with this. Yet, the evidence of recent years with deliberate interference in elections and disinformation campaigns designed to sow divisions and undermine trust in governments points to something darker. Governments have sponsored trolling campaigns to discredit opposition activities and intimidate journalists, suppress dissent, spread lies and manipulate public opinion. Researchers at the University of Oxford found evidence in 2019 of social media manipulation campaigns by governments or political parties in 70 countries, up from 28 in $2017 .{ }^{11}$ According to the report, Facebook was the major platform where disinformation was disseminated. Although Russia is often pointed to as the major source of these campaigns, with its Internet Research Agency in St Petersburg and Advanced Persistent Threat cyber teams in the military intelligence service having received a lot of media attention, China has also become a major player. In August 2019,

9 C. Shirkey, Here Comes Everybody: The Power of Organizing Without Organizations, Penguin, London 2008.

10 R.A. Clarke and R. Knake, 'The Internet Freedom League. How to Push Back against the Authoritarian Assault on the Web' (2019) 98(5) Foreign Affairs 184-192, https://www. foreignaffairs.com/articles/2019-08-12/internet-freedom-league.

11 P. Howard and S. Bradshaw, 'The Global Disinformation Order: 2019 Global Inventory of Organised Social Media Manipulation', https://comprop.oii.ox.ac.uk/wp-content/uploads/ sites/93/2019/09/CyberTroop-Report19.pdf. 
Twitter and Facebook revealed a Chinese state-supported information operation launched globally to de-legitimise the pro-democracy movement in Hong Kong. Twitter announced that it had taken down 936 accounts that were 'deliberately and specifically attempting to sow political discord in Hong Kong. ${ }^{12}$ Facebook said that it had undertaken a similar operation, deleting fake accounts because it does not want its services 'to be used to manipulate people. ${ }^{13}$ The Oxford researchers also found that Russia and China are not alone in weaponising information to gain influence and intimidate opponents. India, Iran, Pakistan, Saudi Arabia and Venezuela were also cited in their report.

As we recognise the dangers that fake news poses - not just in undermining our democracies from within, but also encouraging our adversaries to conduct low-cost/high-gain hybrid warfare against us - the question becomes: what can we do to counter this trend and make ourselves more resilient? In recent times a number of response options have been identified.

First, there are calls for better regulation of the big tech and social media companies, particularly at a time when 'deep fakes' (video or audio clips that literally put words into somebody's mouth) are becoming more widespread and sophisticated. We can debate at length whether giving people the tools to disseminate free speech to a wide audience outweighs the downside of hate speech and over-reliance on a few dominant and centralised information platforms (Google, Facebook, Amazon, etc.). Yet, we cannot dispute the fact that words have consequences and that the tech platforms cannot abdicate their responsibility with simplistic invocations of the right to free speech or that they are mere transmitters of messages with no responsibility for their content and impact, especially at a time when the majority of users are getting their news from social rather than traditional media. There must be a middle way between accepting the benefits of mass access to high-tech communication and hate speech as a regrettable but unavoidable consequence. Public policy needs to find that middle ground, for as Martin Luther King once said: 'Rarely do we find men who willingly engage in hard, solid thinking. There is an almost universal quest for easy answers and half-baked solutions. Nothing pains some people more than having to think.' ${ }^{14}$ Admittedly, social media companies have started to face up to the problem of fake news and misuse of their platforms. In response to public concerns about their enormous power to shape the public psyche, they have introduced more stringent algorithms to weed out fakes and hate speech, and to employ more fact-checkers and to be more sensitive to privacy issues. The question is: can they and should they do more? Should regulation be voluntary

\footnotetext{
12 https://blog.twitter.com/en_us/topics/company/2019/information_operations_directed_at_ Hong_Kong.html.

13 https://newsroom.fb.com/news/2019/08/removing-cib-china.

14 M.L. KING, Strength to Love, Fortress, Philadelphia 1963, p. 2.
} 
or imposed? Is the EU model of data protection and fines for abuse better than the US model of a voluntary public/private sector dialogue?

Next, there is the question of the traditional media. It has suffered at the hands of the Internet and the social media that have accustomed consumers to free content and the expectation that quality journalism can be provided free of charge. Lacking advertising revenue and subscribers, many great newspapers have folded or been forced entirely online. Budgets for foreign news coverage or muck-raking and investigative journalism have dwindled. In an age of fake news, some newspapers have benefited, like The New York Times, which has seen its readership increase as people hanker after reliable, quality journalism. This is not to say that traditional journalism can be restored to its former position and format; it has to adapt to the digital age just like the rest of us. Yet democracy depends on the Fourth Estate and having a broad spectrum of real journalism, which is independent of monopoly business ownership and political influence and control. The question is: without the state owning or subsidising newspapers, TV and radio or online traditional media, what can public policy do to make it easier for traditional quality media to survive and even thrive in the fake news environment? How can it be made more financially viable and safeguarded from political bullying and interference in an age when fake news is increasingly news that politicians do not like and any news is true if it works in their favour?

Another issue concerns political culture. Democracies do themselves no favours when they allow their leaders to demonise TV channels and newspapers as 'enemies of the people' and call on their supporters to forcibly eject journalists from political rallies. Nor do they help themselves when they hold votes, like the Brexit referendum in the UK in 2016, with the public being uninformed, misinformed and generally confused about the issue at hand and with lies and distortions dominating the media debate. Yet this referendum was the most consequential decision in British politics since the end of the Second World War. In an age when political leaders are successful because of their celebrity status rather than the breadth and depth of their intellects, the public is becoming far too forgiving of lies and exaggerations as if these are now a normal part of the political game (and the opposition does it too, right?). The Washington Post regularly publishes a survey of the lies and falsehoods spoken by US politicians and these extend well beyond the current White House. ${ }^{15}$ Yet few political careers are ended by these fabrications, which are inexcusable in an age when everything can be fact-checked instantaneously on Google. Churchill once said that in wartime, truth is so precious that she should always be attended by a bodyguard of lies, ${ }^{16}$ but we are not in wartime. Fake news and disinformation

\footnotetext{
15 Cf. https://www.washingtonpost.com/graphics/politics/trump-claims-database.

16 W. Churchill, The Second World War, Volume V: Closing the Ring, Houghton Mifflin, Boston 1952, p. 338.
} 
will never be countered if democratically elected leaders are their main purveyors and beneficiaries. The good example has to come from the top and the notorious liars and deceivers must be punished at the ballot box. Yet this not only requires a free and vibrant press but also the engagement of civil society more generally. Politicians will pay more respect to the truth when they understand that it is in their interests to do so. Again, what measures and instruments are available to us to combat post-truth politics?

Finally, there is the question of the weaponisation of information as a tactic of hybrid warfare. Because it is below the level of a classical armed attack, provoking a robust, even military response, hybrid warfare is an attractive method for adversaries to test and undermine the resilience of democracies. The Russian interference in the 2016 US presidential election has sounded the alarm bell. Democracies are improving their intelligence gathering and situational awareness, strengthening their cyber-defences and learning from each other's experiences. Gaps and vulnerabilities are being plugged. RT, Sputnik and other purveyors of false reporting are being fined and the Baltic States are even setting up a Russian-language TV station as an alternative to the pervasive presence of Russian stations in the region. Both NATO and the EU have established units to spot and counter fake news campaigns, ${ }^{17}$ and centres of excellence, such as that of NATO in Riga ${ }^{18}$ and the joint EU-NATO centre in Helsinki, ${ }^{19}$ are bringing these two institutions together with the academic and nongovernmental organisation (NGO) communities to analyse the trends and identify the best practices. NGOs like the Digital Forensics Lab at the US Atlantic Council ${ }^{20}$ and Bellingcat ${ }^{21}$ in the UK have performed sterling service in unmasking the organisations and individuals behind the disinformation campaigns. Again, the question is: are these efforts sufficient and commensurate to the challenge of state interference? What more should governments, NATO and the EU do to make such campaigns less attractive and no longer a relatively cost-free instrument of great power competition?

A famous saying from 19th-century American politics, which is often attributed to Abraham Lincoln, states that 'you can fool all of the people some of the time and some of the people all of the time. But you cannot fool all of

17 The EU's European External Action Service (EEAS) has established task forces to deal with fake news and disinformation campaigns, e.g. StratCom East and StratCom South. In turn, NATO has something similar in its Press and Media Service devoted to - in NATO parlance 'myth busting and setting the record straight'.

18 NATO Strategic Communications Centre of Excellence, Riga, Latvia, https://www. stratcomcoe.org.

19 European Centre of Excellence for Countering Hybrid Threats, Helsinki, Finland, https:// www.hybridcoe.fi.

20 https://www.atlanticcouncil.org/programs/digital-forensic-research-lab.

21 https://www.bellingcat.com. 
the people all of the time..22 It would be pleasant to think that democracies will always wake up to their threats - internal and external - and heal themselves in good time before it is too late. Yet today the virtual gulag that China is placing around its Uighur population or the use of information technology and big data to impose a social credit and control system on its citizens, laws in Russia to disconnect itself from the Internet and India's recent total isolation of Kashmir from the outside world by severing all communication links underscore the power of the information weapon to crush the open society and reduce individuals to the status of mere subjects. This is not what the empowerment of humanity via the Internet and social media promised us. Yet, it is not too late to find public policy solutions which can restore information technologies to their original role of facilitators of democracy rather than their undertakers. But the timeframe is closing and we need these solutions sooner rather than later.

This is why the present volume of expert analyses bringing together many academics arrives at just the right time. It aspires to deepen our understanding of the dangers of fake news and disinformation, but also charts well-informed and realistic ways ahead. To my mind, it is certainly one of the most comprehensive and useful studies of this topic to date and I recommend it to the general reader as much as to the policy-maker as a reliable guide and mentor.

Brussels

October 2019

Although this saying has been more reliably attributed to a number of other 19th-century US politicians and the earliest reference is to a Frenchman, Jacques Abbadie, who lived in the 17 th century. 


\title{
INTRODUCTION
}

\section{'They All Hear "Ping" at the Same Time'*}

\author{
Georgios Terzis, Dariusz Kloza, Elżbieta KuŻelewska \\ and Daniel TrottieR ${ }^{* *}$
}

Most people, in fact, will not take trouble in finding out the truth, but are much more inclined to accept the first story they hear.

- Thucydides,

History of the Peloponnesian War (5th century BC)

\section{I.}

This book is motivated, to a large extent, by some recent troubling developments in public discourse, namely the developments in information and disinformation practices. From the beginning of history, various and diverse means or channels of communication have been used to inform, misinform (unintentionally) and disinform (deliberately). However, in recent decades, the emergence and development of new information and communications technologies (ICT), combined with the ever-increasing digitalisation and globalisation of almost every aspect of modern life, among others, have opened up new and uncharted avenues to that end. This book therefore focuses on disinformation practices occurring with the help of digital media as these

\footnotetext{
* Kellyanne Conway, quoted in M.D. Shear, M. Haberman, N. Confessore, K. Yourish, L. Buchanan and K. Collins, 'The Power of Presidential Tweets', New York Times, 13 November 2019, pp. 6-7, https:/www.nytimes.com/interactive/2019/11/02/us/politics/ trump-twitter-presidency.html. All links in this Introduction are valid and accurate as of 28 November 2019.

** Georgios Terzis: Brussels School of Governance (BSG) (an alliance between the Institute for European Studies and Vesalius College), Vrije Universiteit Brussel (VUB), Belgium. Email: Georgios.Terzis@vub.be; Dariusz KlozA: Research Group on Law, Science, Technology and Society (LSTS), Vrije Universiteit Brussel (VUB), Belgium. Email: Dariusz.Kloza@vub. be; Elżbieta Kużelewska: Centre for Direct Democracy Studies (CDDS), Faculty of Law, University of Białystok, Poland. Email: ekuzelewska@gmail.com; Daniel TrotTiER: Erasmus School of History, Culture and Communication; Department of Media and Communication; Erasmus Universiteit Rotterdam (EUR), the Netherlands. Email: trottier@eshcc.eur.nl.
} 
practices bring to the fore profound negative ramifications for the functioning of a democratic polity.

In particular, disinformation - nowadays frequently yet not uncontroversially labelled 'fake news', ' 'alternative facts' or 'post-truth' in English (and imported therefrom to many other languages), 'nepnieuws' in Dutch or 'infox' in French affects the values and principles on which many democratic polities, including the European integration project, ${ }^{2}$ have been built, namely democracy sensu largo, the rule of law (Rechtsstaat) and the respect for fundamental rights. (This classical 'constellation of ideals that dominate our political morality' will be referred to, in this Introduction, simply as 'democracy'.) ${ }^{3}$ Disinformation further affects many other aspects of public life, e.g. political and journalistic practices, all over the world - a development that appears to transcend cultural and political contexts. ${ }^{4}$

From a cursory look at recent history, the 2016 referendum on the departure of the United Kingdom (UK) from the European Union (EU)

1 E.C. TAndoc Jr., Z. Wei Lim and R. Ling, 'Defining "FakeNews". A typology of scholarly definitions', (2018) 6(2) Digital Journalism 137-153.

2 We understand Europe sensu largo - it is a patchwork of supranational arrangements of economic and political nature occurring on the European continent, of individual countries that partake in these arrangements as well as of their inhabitants, regardless of whether they are citizens or not. In geographical terms, this polity comprises the EU with the nonEU members of the European Economic Area (EEA), Switzerland and four microstates Monaco, Andorra, San Marino and the Vatican City/Holy See - that partake with a varying degree in these policies. All of them but the Vatican City/Holy See are members of the Council of Europe (CoE). The Council of Europe, in turn, which is tasked with safeguarding and promoting democracy, the rule of law (Rechtsstaat), fundamental rights and social development, currently comprises - at the time of writing - 47 Member States, i.e. virtually all countries on European soil, with the notable exception of Belarus. Eventually, the EU is a much more closely integrated economic and political union of - at the time of writing 28 Member States. Its main economic component - the internal market - has been open to four other countries - Norway, Iceland and Liechtenstein (linked thereto via the EEA Agreement) as well as Switzerland (linked through bilateral agreements). In parallel, at the regional level, there also exist a few politico-economic unions, such as the Benelux (Belgium, the Netherlands and Luxembourg) and a few loose, political alliances, such as the Visegrád Group (Poland, Hungary, the Czech Republic and Slovakia) or the Weimar Triangle (France, Germany and Poland). Let us borrow a commonly used phrase 'European integration project' to refer, for our purposes, to this patchwork of arrangements.

3 J. WAldron, 'The Rule of Law and the Importance of Procedure', in J. Fleming (ed.), Getting to the Rule of Law, New York University Press, New York 2011, p. 3. For the sake of clarity, it suffices to explain that both the rule of law and Rechtsstaat doctrines serve multiple purposes in a democratic polity and one of them is to channel the exercise of 'public power through law'. They achieve their goals in different manners and hence function differently, while sharing some common characteristics. The rule of law doctrine dominates on the British Isles, while the Rechtsstaat is dominant on continental Europe. Cf. e.g. G. LAutenBACH, The Concept of the Rule of Law and the European Court of Human Rights, Oxford University Press, Oxford 2013, p. 18.

4 M. Moore, Democracy Hacked, Oneworld Publications, London 2018, pp. 246-272. 
(the so-called 'Brexit') and the presidential elections that took place the same year in the United States (US) - and related alleged disinformation practices - have been perhaps the strongest reminder of the importance and the power of disinformation in society, sparking debates in academic, political and artistic circles, and beyond. ${ }^{5}$ In the aftermath, 'post-truth' was declared the word of the year 2016 by, among others, Oxford Dictionaries. ${ }^{6}$ Since then, 'fake news' has been attributed to, inter alia, fuelling the mob killings of five men in the Indian village of Rainpada. Real footage of a chemical attack in Syria was in this case falsely attributed to a nomadic tribe of alleged child abusers. ${ }^{7}$ Nowadays, such stories are plentiful. Eventually, the lapsus linguae of Rudy Giuliani, lawyer to the incumbent US President, such as 'it's somebody's version of the truth, not the truth' or 'truth isn't truth' might be said to 'sum up the spirit' of the contemporary disinformation practices. $^{8}$ However, democratic polities are only at an early stage of understanding the implications of disinformation and digital media.

Consistent with the foregoing, the relations between democracy, on the one hand, and disinformation practices procured with the help of digital media, on the other hand, merit critical analysis and academic attention.

\section{II.}

1. Setting the Scene: Basic Concepts. This book focuses on a number of contested concepts, and first and foremost on 'disinformation', that is, following the Oxford Dictionary of English, 'false information which is intended to mislead, especially propaganda issued by a government organization to a rival power or the media, ${ }^{9}$ for political, personal or financial reasons. The term 'disinformation' might be taken as a synonym for 'misinformation', the latter being 'false or inaccurate information,

5 A number of lengthy books have been written in the aftermath to better understand these developments. Besides the literature cited in this Introduction, cf. e.g. M. D'AnconA, Posttruth: The New War on Truth and How to Fight Back, Penguin, London 2017; J.W. Werner, What is Populism?, Penguin, London 2017; R. Eatwell and M. Goodwin, National Populism: The Revolt against Liberal Democracy, Pelican, London 2018; P. Pomerantsev, This Is Not Propaganda: Adventures in the War Against Reality, Faber \& Faber, London 2019.

6 A. Flood, "Post-truth" Named Word of the Year by Oxford Dictionaries', The Guardian, 15 November 2016, https:/www.theguardian.com/books/2016/nov/15/post-truth-namedword-of-the-year-by-oxford-dictionaries.

7 T. McLaughlin. 'How WhatsApp Fuels Fake News and Violence in India', Wired.com, 12 December 2018, https://www.wired.com/story/how-whatsapp-fuels-fake-news-andviolence-in-india.

8 E. Pilkington, “Truth isn't Truth”: Giuliani Trumps "Alternative Facts” with New Orwellian Outburst', The Guardian, 19 August 2018, https://www.theguardian.com/us-news/2018/ aug/19/truth-isnt-truth-rudy-giuliani-trump-alternative-facts-orwellian. Oxford Dictionary of English, https://www.lexico.com/. 
especially that which is deliberately intended to deceive. ${ }^{10}$ However, as many other commentators, we 'distinguish between misinformation as accidental falsehood and disinformation as deliberate falsehood.' ${ }^{11}$ Both concepts stand in opposition to that of 'information', that is, 'facts provided or learned about something or someone.' ${ }^{12}$ (Yet, 'information' is only one element of the 'knowledge pyramid', in which, hierarchically arranged, 'data precedes information, which precedes knowledge, which precedes understanding and wisdom. ${ }^{13}$ Nevertheless, there exist limits as to what might be known, to the certainty or quality of knowledge, etc. $)^{14}$

The distinction between misinformation and disinformation, on the one hand, and information, on the other hand, is based on the concept of truth. 'Truth' is a foundational characteristic feature of 'facts' - i.e. things 'that [are] known or proved to be true', 'true' signifies 'in accordance with fact or reality', 'accurate or exact', or 'loyal or faithful.' ${ }^{15}$ A 'lie', by contrast, is 'an intentionally false statement' and 'fiction' - 'something that is invented or untrue. ${ }^{16}$ 'Truth' has classically been defined as 'adaequatio rei et intellectus' ${ }^{17}$ however, the very definition of truth carries multiple meanings. ${ }^{18}$ Historians, anthropologists and philosophers have long established that what is true is not only geographically and timely bound, but also depends on the different types thereof. For example, Baggini distinguishes between religious/eternal, esoteric, authoritative, reasoned, empirical, creative, relative, powerful, moral and holistic truths. ${ }^{19}$ Different institutions - such as the state, religious organisations, educational and scientific institutions or family - compete with each other and they will have different

$10 \quad$ Ibid.

11 B.C. Stahl, 'On the Difference or Equality of Information, Misinformation, and Disinformation: A Critical Research Perspective' (2006) 9 Informing Science 86.

12 Oxford Dictionary of English.

13 R. Kitchin, The Data Revolution: Big Data, Open Data, Data Infrastructures and Their Consequences, SAGE, London 2014, p. 10; cf. also H. Cleveland, 'Information as a Resource', The Futurist, December 1982, pp. 34-39.

14 Cf. e.g. S. Funtowicz and J. Ravetz, 'Science for the post-normal age' (1993) 25 Futures 739-755; A. Stirling, 'Precautionary Appraisal as a Response to Risk, Uncertainty, Ambiguity and Ignorance' in C.L. SPASH (ed.), Routledge Handbook of Ecological Economics, Routledge, London 2017, pp. 267-277.

15 Oxford Dictionary of English.

16 Ibid.

17 Latin for 'adequacy of things and thoughts'.

18 As a digression, the Greek word for 'truth' is ' $\alpha \lambda \eta \dot{\eta} \theta \varepsilon ı$ ' (a-lethe-ia), meaning 'un-forgetfulness'. Already in $700 \mathrm{BC}$, Hesiod composed his monumental poem Theogony, in which he explained the genealogy of gods and the origins of the world, and reflected on the sense of importance of truth for the good functioning of organised society. According to him, the goddess Lethe, which is translated as oblivion or forgetfulness, has a very interesting etymology and relatives. Lethe's mother was Eris (Strife). Her brothers and sisters were Algeia (Pain), Machai (Battles), Limos (Famine), Phonoi (Murders) and Dysnomia (Disorder). Lethe's aunt was Apati (Deceit) and her grandfather was Chaos. See G. Antoniou, 'The Lost Atlantis of Objectivity' (2007) 46 History and Theory 92.

19 J. Baggini, A Short History of Truth: Consolations for a Post-truth World, Quercus, London 2017, pp. 11-105. 
levels of power to establish the truth, depending on the issue (faith, health, the environment, defence, the economy, etc.). 'Post-truth', eventually, is an adjective 'relating to or denoting circumstances in which objective facts are less influential in shaping public opinion than appeals to emotion and personal belief'.20

This book is concerned with disinformation procured with the aid of 'digital media'. These media, defined most generally, refer to a set of technologies that individuals and other social actors use to communicate and coordinate with each other. ${ }^{21}$ We understand this term to include both hardware, such as mobile devices, alongside software, such as applications and platforms. Although it is technically possible to consider television and radio as media that are digital, in practice the term 'digital media' is invoked in contradistinction to such forms of broadcasting. In other words, the scholarly and societal importance of 'digital media' lies in their ability to empower atypical media actors, such as those involved in media production who may lack formal credentials, training, skills, etc. - for example, laymen - to engage in activities previously restricted to media professionals, such as credentialed journalists.

Eventually, as a subset of 'digital media', we can identify 'social media platforms' as digitally mediated locations where a user base is compelled to submit information about themselves (including news items they may have read and opinions thereof) as well as consume information about others. ${ }^{22}$ As digital environments, they may be understood as distinct from any given culture or jurisdiction. Yet, in practice, they can become deeply embedded and consequential for the diffuse contexts that they bring together. These platforms nowadays constitute perhaps the key environment in which disinformation practices take place.

2. Research and policy perspectives. What is important then is by whom and how disinformation is established in different societies, how and when it is consumed, and what kind of an impact it has on democracy. First, these new digital media alter the dynamics of disinformation by the three actors of political communication, namely politicians, media and even - these days - the public (citizen journalism). Politicians, for example, might tweet 'fake news' directly to their audience, then journalists working on 24/7 news circles reproduce them instantly and sometimes without the time to verify them, and the public forwards them to millions more of their online 'friends' on social media platforms. Similarly, a number of pieces of 'fake news' might be initiated by the media and

\footnotetext{
20 Oxford Dictionary of English.

21 W.L. Bennett and A. Segerberg, 'Digital Media and the Personalization of Collective Action: Social Technology and the Organization of Protests against the Global Economic Crisis' (2011) 14(6) Information, Communication \& Society 770.

22 D. Trottier, Social Media as Surveillance: Rethinking Visibility in a Converging World, Ashgate, Farnham 2012.
} 
even by citizens, and then have an impact on the media and even political agendas. Obviously, the credibility of those sources of disinformation varies widely, ${ }^{23}$ depending on their institutional role, the mediatisation level of politics, ${ }^{24}$ the specificities of the political system (majoritarian, proportional, etc.) ${ }^{25}$ and the levels of media proliferation and audience fragmentation of different countries, among others.

Second, the nature and the timing of disinformation procured through digital media play a vital role. Communication and political science literature indicate that different types of disinformation practices pose different types and levels of challenges. More obtrusive stories pose different challenges compared to non-obtrusive stories, as well as sensational vs. non-sensational, more negative vs. less negative, widely covered vs. less covered stories, and stories about new issues vs. stories that have been in the public arena for some time. Moreover, research indicates that disinformation poses different challenges during different periods (e.g. election campaigns, emergencies). ${ }^{26}$

Finally, the impact of disinformation is to be distinguished between the three levels on the three different actors (political organisations, the media and the public). The impact might be on a 'purely' informational level, on an attitudinal level or - further - on a behavioural level. All these impacts are equally important and related, but are still different when these are considered as challenges to democracy. Thus, the relationship between disinformation and its effects on democracy is not straightforward. Given the debate in media and communication science on media effects for the past 70 years, during which the society moved from strong to minimal, to medium to conditional ${ }^{27}$ and transactional effects (i.e. uses and gratification), ${ }^{28}$ disinformation in certain cases might be an existential threat while in others - just a nuisance.

3. The importance of facts and truth for the functioning of democracy, and the change of dynamics. That the truth is essential for both private and public life has been known for centuries. Baggini, for example, observed that 'we all have a

23 W.L. Bennett and S. Iyengar, 'A New Era of Minimal Effects? The Changing Foundations of Political Communication' (2008) 58 Journal of Communication 707.

24 J. Sтвӧмвӓск, 'Four Phases of Mediatization: An Analysis of the Mediatization of Politics' (2008) 13(3) International Journal of Press/Politics 228.

25 A. van Dalen and P. van Aelst, 'The Media as Political Agenda-Setters: Journalists' Perceptions of Media Power in Eight West European Countries' (2014) 37(1) West European Politics 42 .

26 S. Walgrave and P. van Aelst, 'The Contingency of the Mass Media's Political Agenda Setting Power. Towards a Preliminary Theory' (2006) 56(1) Journal of Communication 88.

27 D.M. McLeod and G.M. Kosicki, Media Effects: Advances in Theory and Research, Routledge, New York 2009, pp. 228-251.

28 J.G. Webster, 'The Role of Structure in Media Choice: A Theoretical and Empirical Overview' in T. Hartmann (ed.), Media Choice: A Theoretical and Empirical Overview, Routledge, London 2009, pp. 221-233. 
sense that truth is not merely an abstract property of propositions but somehow essential to living well. If your life turns out to have been built on nothing but lies, it is as though it has not been real'. ${ }^{29}$

In public life, one of the key ideas behind democracy is that - rationally speaking - free, equal and engaged citizens of a polity debate peacefully in order to convince their opponents and adversaries to their own viewpoint, with a view to eventually reaching a consensus and deciding on public affairs, for example, in the electoral process. Ideally, their decision should be rational and based on the best available information. It follows that this debate has to be based on facts and hence on truth. This debate is continuous and therefore democracy can be viewed as a process. ${ }^{30}$ Many commentators discussed these building blocks of democracy and, for example, Popper recognised objective knowledge as a foundation of the proper functioning of democratic society. ${ }^{31}$ Downs, in turn, favoured the rationalisation of social life, ${ }^{32}$ where the decision-making process should rely precisely on the best available information. Finding the truth, according to Dahl, constitutes one of the basic conditions for democracy. ${ }^{33}$ To that end, the media constitute an essential means to disseminate information for the purposes of such a democratic debate. Already in the 19th century, for example, while analysing the political and social system of the US, de Tocqueville argued for the local media to facilitate access to knowledge and to tell the truth instead of manipulating the facts. ${ }^{34}$

However, this debate has not always been based on facts and truth; instead, it has been frequently based on lies. Although not all lies are equal, lying has formed part of public - and private - life since the beginning of humanity. Furthermore, as Rosenfeld explains, the democratic idea of truth never quite lived up to its promise of influence by persuasion rather than force. ${ }^{35}$ Nowadays, the 'post-truth' and related phenomena function as a new weapon of political manipulation. Trust in expertise and in institutions has declined, cynicism has risen and citizens are becoming their own information curators. ${ }^{36}$

29 J. BAggini, 'Is This Really a Post-truth World?', The Guardian, 17 September 2017, https:// www.theguardian.com/lifeandstyle/2017/sep/17/is-this-really-a-post-truth-world.

30 Many commentators dealt with the concept of democracy. Cf. e.g. C. Tilly, Democracy, Cambridge University Press, Cambridge 2007.

31 K.R. Popper, Conjectures and Refutations: The Growth of Scientific Knowledge, Routledge, London 1963, p. 292ff; cf. also K.R. Popper, Objective Knowledge: An Evolutionary Approach, Clarendon Press, Oxford 1979.

32 A. Downs, An Economic Theory of Democracy, Harper, New York, 1957, p. 28.

33 R.A. DAhl, On Democracy, Yale University Press, New Haven 2008, pp. 27-28.

34 A. De TocQueville, Democracy in America, Cambridge University Press, Cambridge 1862, pp. $212 \mathrm{ff}$.

35 S. Rosenfeld, Democracy and Truth: A Short History, University of Pennsylvania Press, Philadelphia 2019, pp. 12-14.

36 Ch. Ireton and J. Posetti, Journalism, fake news \& disinformation: handbook for journalism education and training, UNESCO, Paris 2018, p. 19, https://unesdoc.unesco.org/ark:/48223/ pf0000265552. 
To add to this complication, new phenomena and new means of disinformation, such as 'filter bubbles' - i.e. 'personal ecosystem[s] of information ... catered by ... algorithms to who they think you are ${ }^{37}$ - have emerged. In this example, 'filter bubbles' are driven by both a demand side and a supply side. On the demand side is the human predisposition to seek ideologically satisfying news that reinforces existing worldviews. ${ }^{38}$ This results in the 'pleonastic excommunication' created by the plethora of the new media that cannibalise on the time devoted to traditional media consumption that is more likely to include fewer partisan views. ${ }^{39}$ On the supply side is a new media business model that is based on an attention-seeking-and-maintaining digital advertising economy that is successful by maximising the servicing of that demand. ${ }^{40}$ These supply and demand forces that constantly reinforce each other, in combination with the existing and even more extreme ideological segregation of friends and neighbours in most societies (those same friends and neighbours who have also replaced traditional editors of one's newsfeed), ${ }^{41}$ create a vicious circle of polarisation. This makes a compromise - one of the basic premises of democracy - nearly impossible since the population does not share the same facts.

\section{III.}

This book is split into three parts. Part I is entitled 'Theoretical approaches to and the conceptualisation of disinformation'. This begins by providing an overview of various conceptual approaches to disinformation and its redefinition. It further examines their potentially threatening impact on the media, and more broadly - on democracy. A recurring question is whether the fight against disinformation is one of the greatest challenges modern democracies face or whether it is merely an old phenomenon with 'new clothes'.

In Chapter 1, Papakonstantinou opines that the term 'fake news' is inherently wrong because 'news' are facts and facts either are (in which case they cannot be fake) or are not (in which case they are simply lies). However, the

\footnotetext{
37 L. Parramore, 'Eli Pariser on the Future of the Internet', Salon, 8 October 2010, https://www. salon.com/2010/10/08/lynn_parramore_eli_pariser.

38 W.L. Bennett and S. Iyengar, 'A New Era of Minimal Effects? The Changing Foundations of Political Communication' (2008) 58 Journal of Communication 707.

39 G. Terzis and K. Sarikakis, 'Pleonastic Excommunication in the European Information Society' (2000) 17(1-2) Telematics and Informatics 105.

40 E. PARISER, The Filter Bubble: What the Internet is Hiding from You, Penguin, London 2011, pp. 1-20.

41 M. Gentzkow and J.M. Shapiro, 'Ideological Segregation Online and Offline' (2011) 126(4) Quarterly Journal of Economics 1799.
} 
streamlined use of the term shows that it is used mostly as an accusation against news (i.e. facts) that we either do not like per se or do not like the way they are presented. The only thing different from similar phenomena in the past is the Internet and its social media platforms that provide a suitable environment for the deployment of such 'fake news'. However, if we are to find any meaningful way of fighting against them, we need to understand them for what they are and fight against each case separately. Papakonstantinou concludes that 'fake news' deserves no special treatment and should not be the cause of any regulatory intervention.

Daubs demonstrates in Chapter 2 how the term 'fake news' has been redefined by the political right in order to de-legitimise the press. Whereas the press was once seen as the defender of the people and the mediator between the state and its populace, it now needs the populace to defend it at a time when public confidence in the press is at an all-time low. The combination of the deployment of 'fake news' as a combative term to marginalise journalists and the lack of confidence in the press represent a threat to press freedom, the ability for people to be informed and engaged citizens, and - hence - to democracy itself. However, the increasingly frequent attacks on the press and journalists work not only towards limiting the freedom of the press, but are also creating conditions in which journalists themselves are under threat. Through a discourse analysis of comments and online content from the incumbent US President and other government officials, combined with a comparative historical analysis, it is illustrated how the term 'fake news' has been reconfigured into the modern evocation of Lügenpresse, the German propaganda term meaning 'press of lies' used by the Third Reich.

In Chapter 3, Klepka analyses the problem of disinformation and its growing scale, with particular emphasis on 'fake news' as a new communication phenomenon. He indicates the threats to modern democracy posed by new phenomena in the area of mass communication. The main motive of the outlined concept is the presentation of successive sequences of information processing methods, which, together with technological progress, are increasingly distant from neutrality and the idea of reflecting reality. Over time, political bias, which has always been present in the media, began to use human natural predispositions and technical possibilities to create 'echo chambers' and 'filter bubbles'. The latest step in the development of the analysed trend is 'fake news', which, however, seems to be only the next stage in the discussed process and not its final stage. It seems that only adequate preparation to be an aware citizen and responsible consumer of media content can be an attempt to fight the ubiquitous tendency towards disinformation. The pursuit of opposition to disinformation is undoubtedly one of the greatest challenges facing modern democracies.

On the contrary, in Chapter 4, Stocchetti argues that (dis)information is not a threat to democracy, because the political regimes inspired by democratic 
values are based on epistemic and political grounds that neutralise the effects of involuntary or deliberate disinformation in both the social construction of reality and in the competition for control over the use of legitimate power. The main problem with the current debate about (dis)information and democracy is the possibility that undemocratic efforts to control the subversive effects of communicative freedom in the digital age may instrumentalise the genuine concern about the future of democracy. To disambiguate this element of ambivalence, four points are proposed. Amongst these, on the strength of democracy, he concludes that it primarily depends not on the quality of circulating information, but on the quality of its citizens or, more precisely, on the quality of their critical or hermeneutic competences and their resolve to use these competences to think and act on behalf of a shared notion of the public good. Without these competences and determination, there is no imaginable quality of information that can do the trick in their absence.

Chapter 5 investigates the legitimacy of representative democracy in relation to the communicative landscape staged by the digital revolution. Lukkassen concludes that it is not possible to have an honest and sincere representative democracybased on the precondition of communicating with the electorate using modern media. Political and ideological sincerity is no longer indisputable, since for his or her success, a politician depends mainly on factors which transform a people's representative into a media personality. The nature of the medium itself can also influence a discussion or even change its content through the dynamics between the media, velocity and space of communication. However, this does not imply that democracy cannot survive at all under these conditions. 'Democracy of the 19th century is urgently in need of an overhaul in order to be sincere and representative in the 21st century'.

In Chapter 6, Farkas and Schou systematically unpack and critically discuss contemporary 'post-truth' discourses and their democratic underpinnings. Instead of asking whether democracy really is suffering from a 'post-truth' crisis, they examine the discourses presenting this claim with a higher aim of interrogating the very real democratic struggles they contain and foreclose. Democracy is perceived as a truth-telling and rational project concerned with using facts as the foundation for consensus-based political decision-making. This widespread tendency - to take notions like truth, democracy and 'fake news' for granted - is criticised, as these terms are deeply politically and socially charged and constructed, instead of mere descriptions of the world. Instead of seeking to find supposedly 'real' or 'neutral' definitions of 'fake news' and 'post-truth', we need to investigate how they are mobilised as part of political conflicts. In the end, democracy is not just about truth alone; it is about the voice of the people and what they, collectively, deem appropriate.

Barnhizer and Candeub claim in Chapter 7 that 'fake news' undermines the rule of law as it derives its strength from appetitive and emotional responses in a manner that threatens both the rule of law and the willingness of a political 
culture to trust in democratic institutions. The phenomenon of 'fake news' furthermore creates an atmosphere in which political, media and cultural elites can exploit fear about 'fake news' in order to forward their own agenda and undermine democratic institutions in favour of political control by a dominant oligarchic elite. The authors place the 'fake news' concern in the context of media regulation in the US. Looking to the 'elite theory', i.e. a generalisation that nearly all political power is held by a relatively small and wealthy group of people sharing similar values and interests, and mostly coming from relatively similar privileged backgrounds, they suggest that the 'fake news' cause may simply be an elite power grab that US media regulation would allow. The authors eventually suggest that the best response is 'dynamically prophylactic', including active training of individuals to recognise fake news, encouraging greater freedom of expression and resorting to state-based structural responses (e.g. antitrust enforcement).

Part II is entitled 'Experience of dealing with disinformation'. Moving from theory to practice, in this section the authors report insights from dealing with 'fake news', including case studies from the EU and the US. In particular, the authors share experience and their aftermath on why 'fake news' thrives during financial and political crises, whether disinformation was a tool for implementing a security policy and a method for fact-checking.

In Chapter 8, Terzis shares the phenomenon of non-coverage of certain 'truths' using Greece as a case study: during the financial crisis (2009-2018), in its coverage, some of the most important 'true stories' failed to be covered substantially and consistently by the media. The lesson from the Greek financial crisis non-coverage only confirms that in today's globalised economy and political world, liberal democracies cannot afford to neglect having an independent press that oversees at governments' and businesses' possible abuses. A discredited economy and democracy would be restored only through an independent and critical press that reports the 'true stories' that matter, raising the above issues high in its media agenda and thus the public agenda, and forcing politicians to act on these and, by doing so, safeguarding democratic systems.

Experiences from Greece continue in Chapter 9, where Sitistas examines how and why 'fake news' has thrived in Greece, especially during the financial crisis, what it is based upon and what is its impact on the Greek society. Greece was already poorly equipped to battle 'fake news' even before 2009 . The economic crisis that started 10 years ago managed to make things even worse. Greeks already had a poor understanding of what caused the economic downfall and would rather attribute it to 'foreign powers' than accept even the slightest responsibility. From that point on, it was rather easy for 'fake news' and conspiracy theories to thrive, along with populist politicians who took advantage of Greeks' insufficiency of media literacy and populistic journalism. As Greece is emerging from 10 years of harsh austerity, the challenges remain the same. 
In Chapter 10, Reilly discusses the impact of digitally manufactured 'fake news' upon political institutions in Northern Ireland. He does so by first presenting an in-depth study of digital disinformation in 'post-conflict' Northern Ireland through the development of a historical understanding of the role of propaganda in a deeply divided society. Next, he provides an overview of the emergent literature on information disorders, as well as efforts to mitigate their impact on democratic processes, such as elections and referenda. In the absence of a political consensus on how to address complex conflict-legacy issues, digital disinformation looks likely to persist and possibly thrive in this deeply divided society. In this regard, the current genre of information disorders may have much more in common with the 'propaganda war' than was previously thought. A holistic approach towards addressing the causes of information disorder in deeply divided societies such as Northern Ireland is finally proposed.

In Chapter 11, Waśko-Owsiejczuk stresses the use of disinformation and appeal to fear as a tool for implementing US security policy during the presidency of George W. Bush. The terrorist attacks carried out on 11 September 2001 in the US created a convenient situation for the introduction of controversial policy pursued by the White House in the months following the attacks, which in other circumstances would not gain acceptance from either US society or the wider international community. As it turned out, the Bush administration presented false information, thus disinforming the public. The author examines the purpose of the use of disinformation and appeal to fear by the Bush administration and the impact that these tools had on public opinion. The analysis demonstrates how disinformation and propaganda are equally common in democratic polities and not only in authoritarian regimes.

In Chapter 12, Pavleska, Školkay, Zankova, Ribeiro and Bechmann present a study that for the first time integrates theory and practice directly from the 'battlefield' of fact-checking and combating 'fake news' into a novel method for the performance analysis of fact-checking organisations. This method includes the development of a scheme of performance indicators and the definition of a taxonomy of fact-checking systems, supported by an alreadyexisting conceptual framework. The results from the study reveal huge space for improvements in the workflows and the functionality of fact-checkers, and lead to the extraction of a set of recommendations in this regard. The authors make a proposal for a general research and assessment framework for the performance of fact-checking organisations, including the successful 'marriage' between technology, and human efforts and public involvement. In addition to its practical value, this study also contributes to the development of pressing and crucial societal issues and the improvement of democratic and governance processes. 
Part III is entitled 'Solutions to deal with disinformation and their critique' and moves the focus of the book to various proposed measures to deal with disinformation.

Chapter 13 maps the current approach of the European Court of Human Rights (ECtHR) towards disinformation through the inductive analysis of its case law thus far. Hanych and Pivoda identify the Court's approach to various aspects connected with 'fake news', especially those related to the freedom of expression, and the right to respect for private and family life. Even though the ECtHR has not yet had the chance to decide on a case directly concerning the issue of the proliferation of 'fake news', the Court has already commented on several substantial aspects of such a phenomenon. However, the examination of a procedural side of judicial protection indicates some potential drawbacks, such as the identification of a probable perpetrator, which in the cases of the creation or spread of false information online can be per se impossible. Furthermore, even if national legal systems provided for certain kind of appropriate remedies, taking legal action might still be unpredictable and be a rather financially and time-consuming means.

In Chapter 14, Pauner Chulvi discusses the influence of 'fake news' that is placed online and is spread quickly through social media on the freedom of expression and information in the context of the US presidential election, the Brexit referendum and the Colombian referendum (2016). The rise of 'fake news' is becoming a threat to democracy as it constitutes an assault on the right to information, pluralism and the right of citizens to freely form an opinion. Whereas 'fake news' has always existed, what is new now is its proliferation on social media and the lack of any quality control. The challenge posed by 'fake news' requires a paradigm shift in terms of the tools used to combat it and the entities involved in the battle. Fact-checking, the cornerstone of journalistic practice, needs to be the main tool employed in this endeavour. In terms of which parties should be involved in combating 'fake news', calls have been made for the state, the media, technology firms and civil society to participate.

In Chapter 15, Kuczerawy examines the European Commission's Code of Practice on Disinformation, published in September 2018, from the perspective of the right to freedom of expression. Enlisting private sector organisations to regulate the speech of their users may seem to be a practical and efficient approach, as it places the burden directly on the platforms who have the technical means to address the problem. However, it could also be seen as the passing of a 'hot potato' instead of approaching the problem responsibly and in accordance with the rule of law. Thus, it should be accompanied by safeguards that could introduce balance and elements of due process: an addition of a notification, counter-notification or an appeal mechanism, which may slow down the process of handling disinformation. However, a strive for efficiency should not trump the 
respect for fundamental rights. Disinformation is a highly complex problem that requires a proportionate and evidence-based response. Imprudent solutions that do not sufficiently safeguard fundamental rights may lead to unintended consequences on legitimate public debate and - more broadly - democracy.

In Chapter 16, Meyer, Marsden and Brown review policy initiatives relevant to illegal content and disinformation online with the aim of understanding how they recommend the use of technology as a solution to curb certain types of content online and what they identify as the necessary safeguards to limit the impact on the freedom of expression. In particular, they analyse commitments and recommendations made towards transparency in technical interventions aimed at decreasing the prevalence of disinformation. All these policy developments and EU initiatives fit into a context where social media platforms and search engines are increasingly scrutinised on competition grounds and are called upon to take their share of responsibility in the online ecosystem. This chapter thus identifies the limits of technology in regulating content online and makes policy recommendations aimed at ensuring independent, transparent and effective appeal and oversight mechanisms in the use of technology for online content moderation.

In Chapter 17, Archontis takes into consideration the implications that arise from spreading disinformation online and examines not only the factors that led to that problem but also what tools are available to ascertain the accuracy of any given claim encountered online or in the print media. Such tools are available online, and their presentation can help every aspiring fact-checker in developing his or her own skills and improving his or her experience through practice. While writing an original news story may be already a laborious task, fact-checking a published article may sometimes be even more demanding. The purpose of this chapter is not to provide a full documentation of the tools used by every fact-checker, but to help the reader fully grasp the extent of the problem faced regarding 'fake news'.

In Chapter 18, Bentzen builds on the Cambridge Analytica scandal to highlight the lack of definition of 'scientific research' in the General Data Protection Regulation (GDPR) - in the context of personal data processing - as a potential threat to democracy. By not defining 'scientific research', the GDPR may extend the privilege such research affords to an unintentionally broad range of actors and activities; for example, data and research based thereon might be used to manipulate. As an utmost consequence, this could endanger the research participants' legitimate expectations, trust and fundamental rights, and could even endanger democracy as such. Unless the 'scientific research' term is clarified, it cannot function as a safeguard against misuse. There are three main potential assessment criteria to be derived from ECtHR and Court of Justice of the European Union (CJEU) jurisprudence for the assessment of 'scientific research', although these do not provide sufficient safeguards by themselves: the role of the legal entity, the role of the persons carrying out the activity, and 
quality standards, including the scientific method applied. Adding an additional criterion - an ethical assessment including respect for context, inspired by Nissenbaum's theory on contextual integrity - will make the definition of 'scientific research' more robust against cases such as Cambridge Analytica, protecting both individuals and democracy.

Finally, in Chapter 19, an invited contribution, Kritikos comments on the COVID-19 pandemic and a related 'infodemic', ongoing at the time of writing, and analyses, from the lens of democracy, the early efforts to combat mis- and disinformation in the context of scientific uncertainty. Kritikos first overviews the development of the problem, sketching its political, cybersecurity and (public) health dimensions, as well as its consequences for democracy. He presents and evaluates the relevant initiatives to tackle mis- and disinformation at both international and EU levels. He continues by examining some of the informational challenges associated with the spread of falsehood surrounding the pandemic, such as its novelty, and scarcity and the (still) unverified nature of much of the available information. Finally, Kritikos offers a few preliminary suggestions as how to deal with the 'infodemic' while maintaining the democracy standards to which Europe has always adhered to. In particular, he argues that, with regard to fact-checking, inter alia, a strive for efficiency should not trump the respect for fundamental rights and freedoms, and for scientific and ethical plurality. In parallel, open-science and data-sharing initiatives should complement the existing efforts to combat the pandemic and the 'infodemic'.

\section{IV.}

Taking into account the topics discussed in the chapters in this volume, we cannot help but offer a few points of reflection on the past, present and future of disinformation, digital media and democracy in the European integration project.

First, disinformation in public life is nothing new, as for example Papakonstantinou and Daubs also argue in this volume. Misinformation (unintentional) and disinformation (intentional), deception, manipulation, populism, bigotry, conspiracy theories, censorship, propaganda, indoctrination and other distortions of the truth have all been part of democracy since its conception in Athens. (In fact, of any political system.) Already in Plato's Republic, Socrates proposes the 'noble lie', i.e. a fundamental myth of identity and belonging, and of a social structure, that those who govern disseminate to their subjects to organise them, maintain harmony and sustain a political system, e.g. a democracy. ${ }^{42}$ (Speaking even more broadly, civilisations have been

42 Baggini, supra note 19, p. 35. Cf. also M. Schofield, 'The Noble Lie' in G.R.F. Ferrari (ed.), The Cambridge Companion to Plato's Republic, Cambridge University Press, Cambridge 2007, pp. 138-164. 
built on the humane ability to 'create and spread fictions'. ${ }^{43}$ In ancient Rome, in the same vein, it was observed that 'populus vult decipi, ergo decipiatur. ${ }^{44}$ The 20th century alone witnessed, inter alia, the ascent of the Soviet propaganda machine, including the daily newspaper Pravda (Russian for 'truth'), ${ }^{45}$ alongside the Third Reich's Lügenpresse (German for 'press of lies') and even a mantra of propaganda to 'repeat a lie often enough and it becomes the truth', frequently attributed to the Nazi Joseph Goebbels. Development of technology magnified the effects. At the time, thanks to the 'rapidly evolving medium of radio', never before 'had such an efficient tool of manipulating the human mind been available. ${ }^{46}$ At the dawn of 21 st century, disinformation and propaganda are still used to implement controversial security policy, for example in the post-9/11 US, as Waśko-Owsiejczuk explained, and the 'infodemic' challenges decision-making not only in (public) health matters, as Kritikos observed. In addition to altering the present, rewriting the past took place not only in Orwell's Nineteen Eighty-Four, but in reality too - for example, Leon Trotsky, Nikolai Yezhov and perhaps many more communists were erased from Soviet history, having turned from allies into enemies of the state. ${ }^{47}$ The contemporary functioning of the media, even in (still) democratic polities in Europe (e.g. Hungary and Poland), ${ }^{48}$ manipulation and the (rhetorical) attacks on media freedom, even in the US, ${ }^{49}$ are cases in point.

It might require further investigation, but it seems that the term 'fake news' appeared, in the context of the media, for the first time in a 1894 issue of American humour magazine Puck, which published Opper's cartoon 'The Fin de Siècle Newspaper Proprietor. ${ }^{50}$ The drawing shows a 'newspaper owner, possibly meant to be Joseph Pulitzer, sitting in a chair in his office next to an open safe where "Profits" are spilling out onto the floor; outside this scene are many newspaper reporters ... rushing to the office to toss their stories onto the printing press.. ${ }^{51}$ In the picture, one of these stories bears the label 'fake news'.

43 Y.N. Harari, 21 Lessons for the 21st Century, Jonathan Cape, London 2018, pp. 233-234.

44 Latin for 'people want to be deceived, so let them be deceived'.

45 P. Groenendij, 'An Analysis of the Bolshevik Propaganda and its Effectiveness' in I.S. Grat (ed.), Człowiek przeciwko człowiekowi. Filozofia, polityka i prawo a systemy totalitarne, Prymat, Białystok 2008, pp. 75-90.

46 M.K. Albright, Fascism: A Warning, Harper Perennial, New York 2018, pp. 40-41.

47 M. Gessen, 'The Photo Book That Captured How the Soviet Regime Made the Truth Disappear', The New Yorker, 15 July 2018, https://www.newyorker.com/culture/photobooth/the-photo-book-that-captured-how-the-soviet-regime-made-the-truth-disappear; D. KIng, The Commissar Vanishes: The Falsification of Photographs and Art in Stalin's Russia, Metropolitan Books, New York 1997.

48 Cf. e.g. Council of Europe, 'Platform to Promote the Protection of Journalism and Safety of Journalists', (2015-), https://www.coe.int/en/web/media-freedom.

49 Cf. e.g. Reporters without Borders, 'World Press Freedom Index' (2017-), https://rsf. org/en/united-states.

50 F.B. Opper, 'The Fin de Siècle Newspaper Proprietor' (1894), Library of Congress, Washington DC, https://www.loc.gov/resource/ppmsca.29087.

51 Ibid. 
Since this illustrates that disinformation and similar practices are 'nihil novi sub sole, ${ }^{52}$ and in line with the tradition that the European Integration and Democracy book series has established, this very detail has been reproduced on the front cover of this book. Furthermore, the colour of the cover yellow - alludes to the so-called 'yellow press', i.e. the 'use of lurid features and sensationalized news' ${ }^{53}$ this also emerged in the late 19 th century, alongside the term 'fake news. ${ }^{54}$

Second, disinformation and similar practices only seem new due to their form, dynamics and - as we discussed in the opening paragraph - their (frequently controversial) label: these have changed over time, as observed in this volume by Klepka. The essence nonetheless has remained. Each era brings new tools of communications, from word of mouth, to the written word, to the invention of the telegraph, the computer and the Internet. The characteristics of the latter means of communication, such as speed, cost and the overcoming of the constraints of distance, brought completely unprecedented dimensions of disinformation. One of the paradoxes of these new technologies, and of digital media that run thereon, is that of a possibility of their use for both licit and illicit ends. These technologies might be at the same time fostering and suppressing democracy, as illustrated in this book by Lukkassen, Farkas and Schou, and Barnhizer and Candeub. For example, while digital media make it possible to express oneself more freely, e.g. during an electoral campaign, they also allow for direct contact between politicians and the citizenry. As a case in point, Twitter has become the prime communication tool of the incumbent US President. Kellyanne Conway, Donald Trump's advisor, once commentated that it was 'the democratisation of information' as '[t]hey all hear "ping" at the same time. ${ }^{55}$ Yet, this is only one side of the coin. At times, this direct contact - which is quite a novelty - comes at the expense of democracy, for example the integrity of the electoral process, due to manipulation, as this does not help the citizenry making an informed choice, ${ }^{56}$ as Pauner Chulvi, Bentzen and Reilly highlighted.

Third, 'fake news' is often characterised as a tension between traditional media and new actors on social media platforms, while we contend that we

52 Latin for 'nothing new under the sun'.

53 Cf. B. Duignan, 'Yellow Journalism', Encyclopaedia Britannica, 2019, https://www.britannica. com/topic/yellow-journalism.

54 W.J. Campbell, Yellow Journalism: Puncturing the Myths, Defining the Legacies, Praeger, Westport 2001.

55 Cf. supra, first asterisked note.

56 Cf. e.g. C.J. Bennett, 'Voter Databases, Micro-targeting, and Data Protection Law: Can Political Parties Campaign in Europe as They Do in North America?' (2016) 6(4) International Data Privacy Law 261; C.J. BennetT and S. Oduro-Marfo, Privacy, Voter Surveillance and Democratic Engagement: Challenges for Data Protection Authorities, Office of the Information Commissioner, Wilmslow 2019, https://privacyconference2019. info/wp-content/uploads/2019/11/Privacy-and-International-Democratic-Engagement_ finalv2.pdf. 
are in fact not witnessing a radical displacement of 'the usual suspects' behind disinformation campaigns. Although it is tempting to position conventional journalism and related practices like fact-checking as endangered by the growth of digital platforms, in practice there is a more symbiotic relationship between these entities, a factor also observed by Archontis. Journalists do not work against social media platforms, but rather within and through these. ${ }^{57}$ We may speculate that both conventional press and digital platforms are beholden to a business model that privileges attention-seeking and audience engagement, which in turn redirects traditional news values and selection criteria, and consequentially journalism and media ethics. Moreover, even when the so-called political or journalistic 'nobodies' are responsible for prominent 'fake news' incidents, as in the cases presented by Terzis and Sitistas, their efforts are more likely to inform existing press or political activity rather than simply disrupt it. ${ }^{58}$

Fourth, this book has probably proven the obvious that the efforts thus far to combat disinformation and similar practices have been rather insufficient, as, for example, Pavleska et al., Meyer et al. and Kritikos have argued. (Some commentators, however, question the very need for any reaction to 'fake news', e.g. Papakonstantinou, or argue that the problem lies elsewhere, e.g. Stocchetti, or suggest to first use the existing avenues, e.g. Hanych and Pivoda.) While many other commentators have lamented that, in the public sphere, 'falsehoods are mostly left unchallenged, ${ }^{59}$ reactions to the new dimensions of disinformation, if undertaken, can range from some organisational and technological measures to regulatory ones. While the former include fact-checking (human-led, technology-led, or both) and journalism education, ${ }^{60}$ the latter can vary from mild self-regulation (e.g. codes of practice) to even outright imposition of (criminal) liability (e.g. laws against defamation, unfair commercial practices, competition or against Holocaust denial). However, as Stocchetti observes, a high level of education of the citizenry - in addition to (digital) media literacy, their awareness, critical hermeneutic competences, resilience, vigilance and some common sense - is frequently proposed as one of the remedies. ${ }^{61}$ At times, journalists and media outlets are reminded that truthfulness is one of the basic principles of any code of ethics of their profession and that members of a democratic polity would normally expect them to observe these codes

57

A. Chadwick, The Hybrid Media System: Politics and Power, Oxford University Press, Oxford 2017, p. 4.

58 D. Trottier, 'Scandal Mining: Political Nobodies and Remediated Visibility' (2017) 40(6) Media, Culture \& Society 903.

59 Р. ОвоRne, 'It's not just Boris Johnson's lying. It's that the media let him get away with it', The Guardian, 18 November 2019, https://www.theguardian.com/commentisfree/2019/nov/18/ boris-johnson-lying-media.

60 Cf. IREton and Posetti, supra note 36.

61 Cf. e.g. H. Davies, 'Why Education is the Only Antidote to Fake News', The New Statesman, 19 February 2018, https://tech.newstatesman.com/guest-opinion/education-antidote-fakenews. 
of conduct. ${ }^{62}$ In addition, many media outlets have a reputation to uphold. Most scholars and policy-makers seem to agree. Nevertheless, more is needed. Some commentators argue further that more time and effort should be invested in combating disinformation by, for example, diversifying sources of information and their comparison, and be willing to pay credible media outlets for reliable information. ${ }^{63}$ However utopian the suggestion that all the citizenry should be informed about all public affairs, that an individual has sufficient means to verify what is true and what is not, and that total transparency is feasible or even desirable, the fight against disinformation should be perceived as a shared competence among various actors and a combined use of different tools (cf. Pauner Chulvi).

Fifth, some of the efforts to fight disinformation might conflict with the values and principles on which a democratic polity has been built, as many commentators have stressed, and - in this volume - Stocchetti, Kuczerawy, Bentzen, and Hanych and Pivoda have struck the same chord. As the most mundane examples, the proposed 'ministries of truth' would challenge due process (fair trial) or, simply, falsehood might be afforded protection set by the freedom of expression (free speech), ${ }^{64}$ hence largely limiting the intellectual and legal 'arsenal' to fight disinformation. Yet, human rights law - at least in theory - already has known the solution to how two or more seemingly conflicting human rights, freedoms or - broadly - individual and collective interests can walk together. To a large degree, the answer lies in the principle of proportionality. Proportionality 'was originally used by Euclid as a mathematical term relating to relationships between shapes' and was subsequently transposed to other domains, such as aesthetics and ethics. ${ }^{65}$ In law, its contents have been formulated in different terms by commentators and courts alike. ${ }^{66}$ Typically,

62 S.R. Stroud, 'Pragmatist Media Ethics and the Challenges of Fake News' (2019) 34(4) Journal of Media Ethics 178-192. Cf. also e.g. P.L. Plaisance, Media Ethics: Key Principles for Responsible Practice, SAGE, London 2013; Society of Professional Journalists, SPJ Code of Ethics, 2014, https://www.spj.org/ethicscode.asp; Accountable Journalism, Codes of Ethics: International, n.d., https://accountablejournalism.org/ethics-codes/international; The New York Times, Ethical Journalism. A Handbook of Values and Practices for the News and Editorial Departments, n.d., https://www.nytimes.com/editorial-standards/ethicaljournalism.html.

63 HARARI, supra note 43, pp. 243-244.

64 Cf. e.g. D. Voorhoof, Freedom of expression, the media and journalists: case-law of the European Court of Human Rights, Council of Europe, Strasbourg 2015; D. Voorhoof, 'Same standards, different tools? The ECtHR and the protection and limitations of freedom of expression in the digital environment', in M. O'Boyle, Human Rights Challenges in the Digital Age: Judicial Perspectives, Council of Europe, Strasbourg 2020, pp. 11-46.

65 K. MaCNish, 'An Eye for an Eye: Proportionality and Surveillance' (2015) 18(3) Ethical Theory and Moral Practice 529, 534.

66 D. Lindsay, 'The Role of Proportionality in Assessing Trans-Atlantic Flows of Personal Data' in D. Svantesson and D. Kloza (eds.), Trans-Atlantic Data Privacy Relations as a Challenge for Democracy, Intersentia, Cambridge 2017, p. 53. 
proportionality could involve up to four components: legitimacy (i.e. whether a measure intended to intrude on the enjoyment of a human right has an 'objective of sufficient importance'); ${ }^{67}$ suitability (i.e. whether it is 'capable of achieving' this legitimate objective); ${ }^{68}$ necessity (i.e. 'whether the measure is necessary to achieve that aim, namely, whether there are other less restrictive means capable of producing the same result'); and proportionality stricto sensu (i.e. 'even if there are no less restrictive means, it must be established that the measure does not have an excessive effect' on one's interests). ${ }^{69}$ If found disproportionate on any of these ground, the measure would be - at minimum - illegal.

Sixth and finally, as Huxley once observed, 'life is short and information endless. ${ }^{70}$ Fighting disinformation and related practices is a strenuous exercise, particularity due to an abundance of information and, in parallel, a scarcity of resources to address the problem. The COVID-19 'infodemic' is a case in point, which has further highlighted the difficulties in decision-making in both public and private life. The dilemma is precisely how to act in situations in which 'facts are uncertain, stakes high, values in dispute and decisions urgent. ${ }^{71}$ Traditionally, science is meant to offer a solid base, largely quantitative predictions, for informed decision-making and the abundance of falsehoods stands in opposition thereto. But in a situation like a pandemic, such predictions are limited and unreliable (as e.g. information is novel, out of context, incomplete and, frequently, unverified), and, in the 'infodemic', furthermore, truth is difficult to distinguish from falsehood or e.g. sensationalism, while decisions must be taken immediately. This recalls Funtowicz and Ravetz's 'post-normal' approach to science, and more concretely using it for decision-making processes. ${ }^{72}$ Postnormal science joins the chorus of appeals to democratise science and resort to an 'extended peer community', i.e. 'the knowledge base should be pluralized and diversified to include the widest possible range of high-quality potentially usable knowledges and sources of relevant wisdom, without enforcing the demand for science to speak with one voice. ${ }^{73}$ Admitting the uncertainty of information, post-normal science emphasises not only the gathering of information (i.e. public participation), but also its quality assurance through multiple channels.

F. URbina, 'A Critique of Proportionality' (2012) 57(1) American Journal of Jurisprudence 49. M. KLatt and M. Meister, 'The Structure of the Proportionality Test' in The Constitutional Structure of Proportionality, Oxford University Press, Oxford 2012, p. 8.

T. Tridimas, The General Principles of EU Law, Oxford University Press, Oxford 2013, p. 139.

A. Huxley, Brave New World Revisited, Random House, London 1958, p. ix.

S.O. Funtowicz and J.R. Ravetz, 'Science for the Post-Normal Age' (1993) 25(7) Futures 744. Ibid., 739-755.

D. Waltner-Toews, A. Biggeri, B. De Marchi, S.O. Funtowicz, M. Giampietro, M. O'Connor, J.R. Ravetz, A. Saltelli and J.P. Van Der Sluijs, 'Postnormal pandemics: Why COVID-19 requires a new approach to science', STEPS, 25 March 2020, https:// steps-centre.org/blog/postnormal-pandemics-why-covid-19-requires-a-new-approach-toscience/. 
Hence, it is not surprising that Kritikos argues, inter alia, for a coordinated opening up of the repositories of non-personal data (open data) and more robust fact-checking by media outlets, governed by a dedicated ethical code of conduct.

To conclude, in order for a democratic polity - in which we see intrinsic value - to exist and flourish, it is indispensable that it is based on facts and, hence, truth, to the extent that these are attainable. There are instances in which fiction, satire and fantasy are desirable, such as an artistic recounting of events that may exaggerate or even fabricate certain details. Disinformation and comparable practices, in contrast, negatively affect the very building blocks of democracy. As undesirable as this may be, misinformation (unintentional) and disinformation (intentional) may always feature in democratic debate, within the boundaries of the freedom of expression (free speech) and decency, yet falsehood must be clearly designated as such each time. In other words, the citizenry has to be able to distinguish fact from fabrication and - to paraphrase the epigraph not to 'to accept the first story they hear', suggesting the need for a capacity to draw distinctions (e.g. true vs. false, fact vs. interpretation) as well as for media literacy that extends beyond being technologically savvy. Having heard 'ping', the choice of what to do with clearly labelled 'fake news' nonetheless rightly remains in their hands.

Democracy is a process and it would be naïve to conclude it was a given. Already in 1939, Dewey argued against the belief that 'democratic conditions automatically maintain themselves, or that they can be identified with fulfilment of prescriptions laid down in a constitution. ${ }^{74}$ In his Foreword to this volume, Shea too observes that 'it would be pleasant to think that democracies will always wake up to their threats - internal and external - and heal themselves in good time before it is too late. ${ }^{75}$ Instead, as Voltaire's Candid said, 'il faut cultiver notre jardin'76 and this 'cultivation' would also mean a 'commitment to culture, to civility, to civilization itself ${ }^{77}$ so that 'a piece of the world' is improved. ${ }^{78}$ All in all, democracy is an Aristotelian habit to be practised and upheld equally by those who govern and by those who are governed. ${ }^{79}$

\footnotetext{
74 J. Dewey, Freedom and Culture, G.P.Putnam's Sons, New York 1939, p. 34.

75 J. SHEA, 'Foreword' in this volume.

76 French for 'We must cultivate our garden'. Voltaire, Candide, Le Livre de Poche, Paris 1997 [Geneva 1759], p. 167.

77 R. Darnton, 'To Deal With Trump, Look to Voltaire', The New York Times, 27 December 2018, p. 19, https://www.nytimes.com/2018/12/27/opinion/trump-voltaire-enlightenment. html.

78 W. Berry, Think Little: Essays, Conterpoint, Berkley 1972.

79 Cf. 'For by acting as we do in our dealings with other men, some of us become just, others unjust; and by acting as we do in the face of danger, and by becoming habituated to feeling fear or confidence, some of us become courageous, others cowardly [...] So it is not unimportant how we are habituated from our early days; indeed it makes a huge difference or rather all the difference'. Aristotle, Nicomachean Ethics, tr. R. CRisp, Cambridge University Press, Cambridge 2000, 1103 b.
} 
In this process, for such a democratic polity to face disinformation practices procured with the aid of digital media, there exists many responses, and e.g. hermeneutic competences and the principle of proportionality - of course are not the sole ones. In the previous volume in this book series, devoted to irregular migration as a challenge for democracy, ${ }^{80}$ its editors have argued, inter alia, for the adherence to the foundational values and principles on which the European integration project - and any other democratic polity - was founded, for an ethical reflection, and for greater decency and moderation of public debate in dealing with irregular migrants. ${ }^{81}$ It is not surprising that these postulates recall a 'commitment to [...] civilization' and are equally valid for dealing with disinformation and digital media.

\section{V.}

The book constitutes the sixth volume in the European Integration and Democracy series. The Series was launched in 2011 and is edited at the Centre for Direct Democracy Studies (CDDS) at the Faculty of Law of the University of Białystok, Poland. Since 2014, Belgo-British Intersentia publishes our series. Each volume in the series tackles a pressing issue that is of utmost importance for the European integration project and - at the same time - that poses a challenge to the values and principles on which Europe has been built. Thus far, our books have discussed, through that lens, the elections to the European Parliament, transatlantic data privacy relations or - as already mentioned irregular migration. ${ }^{82}$

Like all volumes published thus far in this series, this book originated from a call for papers, which was issued in May 2018. Yet again, the response received was indicative of the topicality of the chosen subject matter and the variety of interest from academic scholarship. Authors originate from academia, government institutions and non-governmental organisations, among others.

80 Cf. infra, section V.

81 E. Kużelewska, A. Weatherburn and D. Kloza, 'Introduction: Asking Big Questions: Migrants Ante Portas and What to Do with Them?' in E. Kużelewska, A. Weatherburn and D. Kloza (eds.), Irregular Migration as a Challenge for Democracy, Intersentia, Cambridge 2018, pp. xiii-xlvii.

82 The previous volumes are: E. Kużelewska and D. Kloza (eds.), The Challenges of Modern Democracy and European Integration, Aspra-JR, Warsaw 2012; E. KużelewskA and D. KlozA (eds.), Elections to the European Parliament as a Challenge for Democracy, Aspra-JR, Warsaw 2013; E. Kużelewska, D. KlozA, I. Kraśnicka and F. Strzyczkowski (eds.), European Judicial Systems as a Challenge for Democracy, Intersentia, Cambridge 2015; D.J.B. Svantesson and D. Kloza (eds.), Trans-Atlantic Data Privacy Relations as a Challenge for Democracy, Intersentia, Cambridge 2017; E. Kużelewska, A. Weatherburn and D. Kloza (eds.), Irregular Migration as a Challenge for Democracy, Intersentia, Cambridge 2018. 
All submissions underwent a double-blind peer-review process in accordance with the Guaranteed Peer-Review Content (GPRC) scheme, a standard used by Intersentia. ${ }^{83}$ As a result of this careful selection process, 18 submissions were accepted. In addition, given the impact of the COVID-19 pandemic on the functioning of a democracy, in April 2020 we welcomed an invited contribution that reflects on the on-going developments and their relations to mis- and disinformation, which resulted in an essay included in this book as the 19th chapter.

This book does not aspire to be a monograph on disinformation, digital media and democracy in Europe; rather, it is an anthology compiling diverse yet rich academic and professional comments on a wide range of pressing issues within a broad topic. It is meant to contribute to a debate and a reflection on the condition of our democracy at the dawn of the third decade of the 21 st century. We have been exceptionally careful in allowing the authors to express their ideas as they wish to, with only minimal editorial intervention. Our intention is that this book will act as both a commentary and reference work, and will reach not only our fellow academics in Europe and beyond, but also policy-makers, civil society organisations and journalists concerned with disinformation, digital media and democracy in Europe and beyond.

VI.

Every book is a product of a team. We thank the authors and congratulate them for their contributions, which have been further bolstered by the apt and thought-provoking Foreword. For that, our gratitude and thanks go to Jamie Shea, former official of the North Atlantic Treaty Organization (NATO), where he held the posts of spokesperson (1993-2000) and Deputy Assistant Secretary General for Emerging Security Challenge (2010-2018), among others. We particularly thank Ioulia Konstantinou, Managing Editor of the series. We thank the peer-reviewers who have all contributed to ensuring the scientific quality and integrity of this volume. We have received with gratitude further help from Rocco Bellanova, Simone Casiraghi, Laura Drechsler and Mihalis Kritikos. Once again, we thank Intersentia, and our publisher Tom Scheirs and editor Rebecca Moffat. Finally, we gratefully acknowledge the financial support received for this book from the Vrije Universiteit Brussel (VUB) and the Faculty of Law of the University of Białystok.

Brussels - Białystok - Rotterdam

November 2019-April 2020

83 Cf. http://www.gprc.be/en/content/what-gprc. 



\section{CONTENTS}

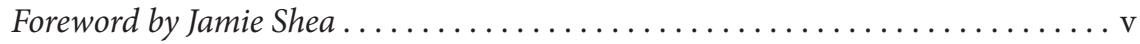

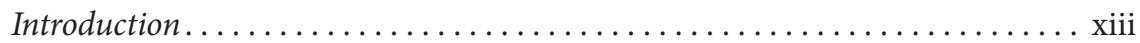

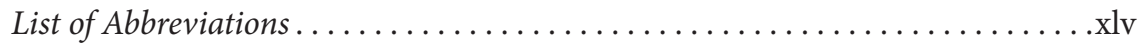

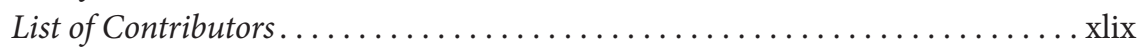

PART I. THEORETICAL APPROACHES TO AND THE

CONCEPTUALISATION OF DISINFORMATION

1. Should We be Afraid of Fake News?

Vagelis Papakonstantinou $\ldots \ldots \ldots \ldots \ldots \ldots \ldots \ldots \ldots \ldots$

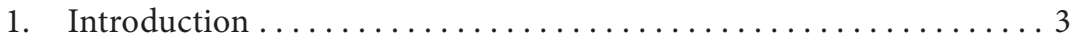

2. What is 'Fake News' Exactly? ................... 3

2.1. 'Fake News' as Lies...................... 4

2.2. 'Fake News' as (Nuanced) Facts . . . . . . . . . . . . 5

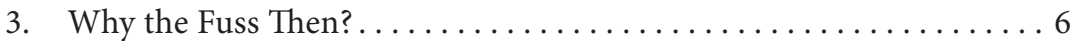

4. The Internet Effect ....................... 7

5. Conclusion: Keep Calm and Carry On ................ 9

2. From Misinformation to Modern Lügenpresse: The Redefinition of Fake News

Michael S. Daubs ....................... 11

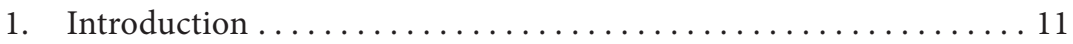

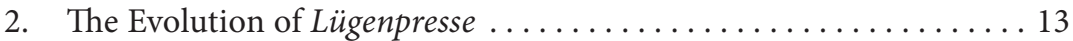

3. Fake News from Satire to Disinformation. . . . . . . . . . . 17

4. Fake News as Kampfbegriff ........................ 23

5. Concluding Remarks .......................... 29

3. Information and Disinformation and the Transformation of Modern Democracy: From Media Bias through the 'Echo Chamber' and the 'Filter Bubble' to Fake News

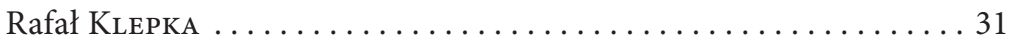

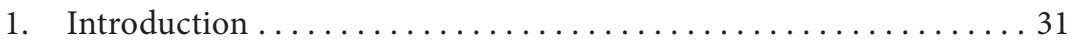

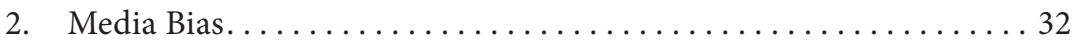


3. The 'Echo Chamber' and the 'Filter Bubble' ................ . 35

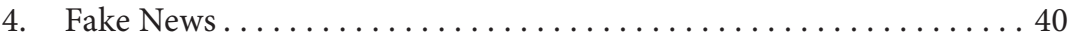

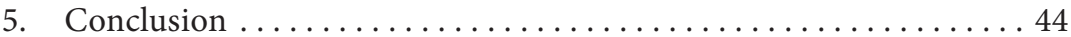

4. (Dis)Information, Neoliberalism and the Strength of Democracy in the Digital Age

Matteo Stocchetтi........................ 47

1. Introduction: (Dis)Information, Power and Ideology . . . . . . 47

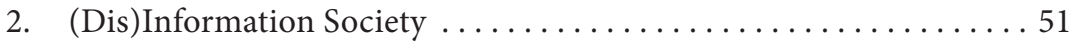

3. The Constructionist 'Revolution' and Postmodernism . . . . . . . . 54

3.1. The Constructionist 'Revolution' . . . . . . . . . . . . . . 54

3.2. Postmodernism: The Culture of Late Capitalism and its Radical Critique. .................. 56

4. Information, Capitalism and Democracy ............6 60

4.1. The 'Democratic Crisis of Capitalism' ................ 64

4.2. The New International Information and Economic Order . . . 68

4.3. The Crisis of Neoliberal Democracies: Communicative Freedom and Securitisation . . . . . . . . . . . . . 71

5. Conclusions: The Strength of Democracy ............. 76

\section{Democracy and the Pre-Conditions of Communication}

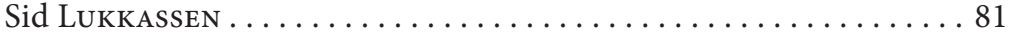

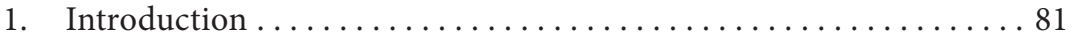

2. The Digital Evolution in Representative Democracy .......... 82

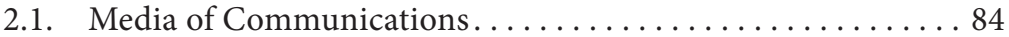

2.2. Velocity of Communications $\ldots \ldots \ldots \ldots \ldots \ldots \ldots \ldots \ldots$

2.3. Space of Communications $\ldots \ldots \ldots \ldots \ldots \ldots \ldots \ldots \ldots$

3. Political Modelling. .......................... 87

4. The Mediative Influence Upon Politics and Vice Versa . . . . . . . . . 89

5. Velocity of Communications and Politics: Framing and Priming . . . 93

6. Communicative Space and Politics . . . . . . . . . . . . 95

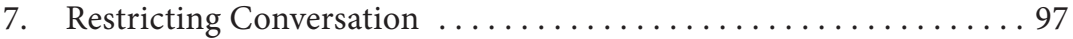

8. The Rise of Symbol Analysts . . . . . . . . . . . . . . . . . . 99

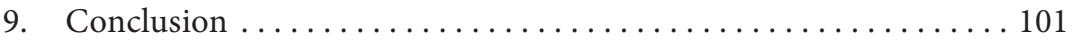

6. Post-Truth Discourses and their Limits: A Democratic Crisis?

Johan FARKAS and Jannick Schou . . . . . . . . . . . . . . 103

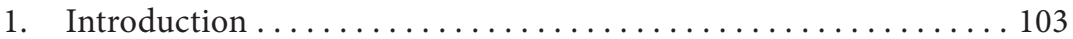

2. Approach and Method......................... 105 
3. Mapping Post-Truth Discourses. . . . . . . . . . . . . . 108

3.1. What is Wrong? ........................ 108

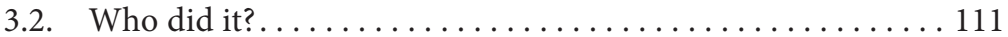

3.3. What is to be Done? ...................... 117

4. Discussion: The Dangers of Post-Truth Discourses . . . . . . . . . 120

5. Conclusion ................................. 123

7. Elite Theory, Media Regulation and 'Fake News'

Daniel Barnhizer and Adam Candeub . . . . . . . . . . 127

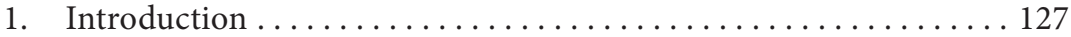

2. Defining 'Fake News' .......................... 127

3. Elite Theory and the Fake News Phenomenon ............ 134

4. Media Regulation and Media Elites . . . . . . . . . . . . . . 138

5. Elite Circulating: From Television and Radio Networks

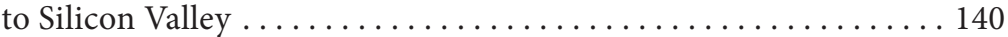

6. Responding to Fake News . . . . . . . . . . . . . . . . 142

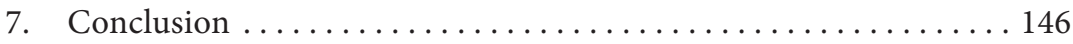

\section{PART II. EXPERIENCE OF DEALING WITH DISINFORMATION}

8. True Story! Challenges to Democracy not Covered by the Media: Lessons from the (Non-)Coverage of the Greek Financial Crisis

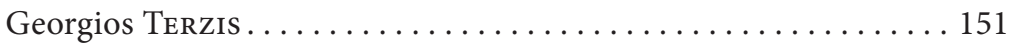

1. Introduction . . . . . . . . . . . . . . . . . . . . 151

2. News Selection and the Non-Covered 'Truths' of the Greek Financial Crisis. . . . . . . . . . . . . . . . . . . . . . . . . . . . . . 153

2.1. True Story 1: The Non-Meritocracy Catch-22 of Greek Political Parties .......................... 153

2.2. True Story 2: 'Corruption Competition': The Epidemic that Infests Everything and Erodes Basic Trust . . . . . . . . 154

2.3. True Story 3: There are No 'Shields' to Protect from the Globalisation 'Barbarians' . . . . . . . . . . . . . . 155

3. Lessons Learnt: Media Watchdogs, Media Lapdogs, Greek Donkeys and the 'Big Fat Greek Funeral' Media Festival . . . . . . . 156

4. Epilogue.................................. 157

5. The Road Ahead and the Role of the 'True' News Stories . . . . . . . 159

9. The Scourge of Fake News in Greece

Thanos Sitistas . . . . . . . . . . . . . . . . . . 161

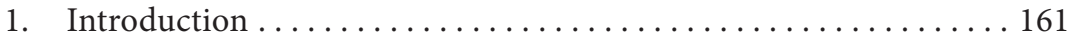

2. What do Greeks Read on the Internet? . . . . . . . . . . . . 162 
3. Common Misconceptions........................ 163

4. The Russian Paradox . . . . . . . . . . . . . . . . . . . . . . 165

5. To Ksantho Genos: The Blond Race . . . . . . . . . . . . . . . 167

6. Economic Crises and Fake News in Greece . . . . . . . . . . . . . . . 169

7. The Economic Crisis and Conspiracy Theories ........... 172

8. The Greek Problem of Media Literacy and Freedom of the Press ................................ 173

9. Greece and Populism: A Recent Example ............... . 174

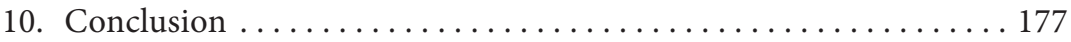

10. Digital Disinformation in a Deeply Divided Society:

Reflections from Northern Ireland

Paul Reilly . . . . . . . . . . . . . . . . . . . . . . . . . . . . . 179

1. Introduction . . . . . . . . . . . . . . . . . . . . . . . 179

2. The Challenge of 'Fake News' to Media and Politics . . . . . . . . 180

$2.1 \quad$ Fake News and Trust in Mainstream Media.... . . . . . . . . 180

2.2. Information Disorders $\ldots \ldots \ldots \ldots \ldots \ldots \ldots \ldots \ldots \ldots \ldots$

3. The Propaganda of War and Peace in Northern Ireland . . . . . . . . 185

4. Social Media, Disinformation and Hybrid Media Events in Northern Ireland . . . . . . . . . . . . . . . . . . . . . 188

4.1. The 2012 Union Flag Protests. . . . . . . . . . . . . . . 189

4.2. The 2014 and 2015 Ardoyne Parade Disputes ... . . . . . . . 191

4.3. Effects of Digital Disinformation may be Difficult to Detect. . . . . . . . . . . . . . . . . . . . . . . . . . 194

5. Building Societal Resilience against Digital Disinformation . . . . 195

6. Conclusion ............................. 197

11. Disinformation and Fear Propaganda as Justification for the War on Terror During George W. Bush's Presidency

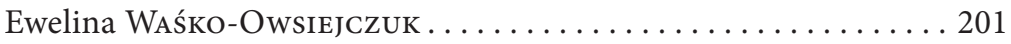

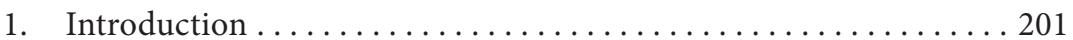

2. Disinformation and Propaganda: Theoretical Aspects . . . . . . . 202

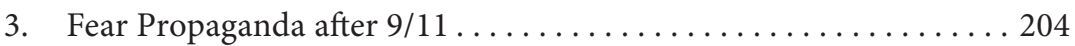

4. The War on Terror: Desperate Times Call for Desperate Measures ... . . . . . . . . . . . . . . . . . . . . . . . . . . . . . . . . . 207

5. The War in Iraq: In Search of an Excuse ............... 210

6. The Presidential Election in 2004 in the Shadow of the War on Terror . . . . . . . . . . . . . . . . . . 213

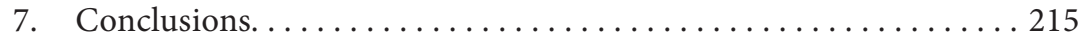


12. Performance Analysis of Fact-Checking Organisations and Initiatives in Europe: A Critical Overview of Online Platforms Fighting Fake News

Tanja Pavleska, Andrej Školkay, Bissera Zankova,

Nelson Ribeiro and Anja Bechmann. . . . . . . . . . . . . . 217

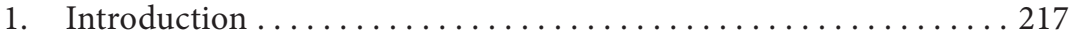

2. Background Concepts and Related Work .............. 220

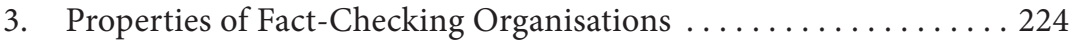

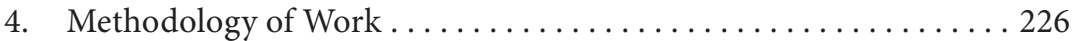

4.1. Developing Performance Indicators . . . . . . . . . . . . 227

4.1.1. Performance Indicators Relevant for Non-Governmental Organisations............ 227

4.1.2. Performance Indicators from Governmental

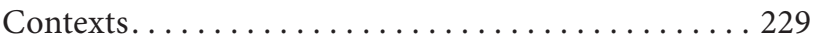

4.2. The WDF Conceptual Framework. ............... 231

4.3. Mapping the WDF to the Context of Fact-Checking . . . . . 232

5. Empirical Study ............................... 234

5.1. Results and Analysis ..................... 235

5.1.1. Efficiency of Fact-Checking Organisations ........ 236

5.1.2. Effectiveness of Fact-Checking Organisations ..... 238

5.2. Discussion ......................... 242

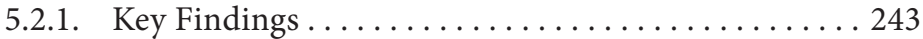

5.2.2. Recommendations ................... 244

6. Conclusion and Future Work ................... 246

\section{PART III. SOLUTIONS TO DEAL WITH DISINFORMATION} AND THEIR CRITIQUE

\section{Disinformation and Fake News in Current Jurisprudence} of the Strasbourg Court: An Unsolved Problem Monika Hanych and Marek Pivoda . . . . . . . . . . . . . . . . . . . . 249

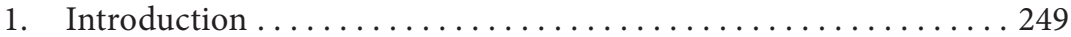

2. Concept and Definition of Fake News/Disinformation . . . . . . . . 250

3. The Development of the Court's Approach to the Issue of Disinformation/Fake News. . . . . . . . . . . . . . . . . . . . . . 252

3.1. Fake News and Disinformation within the Scope of Freedom of Expression . . . . . . . . . . . . . . . 253

3.1.1. Preliminary Observations ................ 253

3.1.2. Legitimate Aim and Striking the Balance ........ 256 
3.2. Fake News and Disinformation within the Scope of the Right to Respect for Private and Family Life . . . . . . . 261

3.2.1. Preliminary Observations ............... 261

3.2.2. Legitimate Aim and Striking the Balance ........ 262

4. Identifying Key Actors in Judicial Proceedings: Why does it Matter? . . . . . . . . . . . . . . . . . . . . . . . . . . . . . . . . . . . . . . . 265

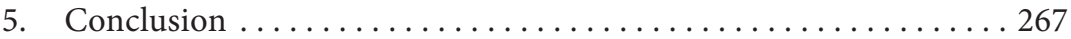

14. Fake News and Freedom of Expression and Information: The Legal Framework and Policy Actions at the EU Level to Address Online Disinformation

Cristina Pauner Chulvi. . . . . . . . . . . . . . . . . . . . . . . . . . . . . . . 269

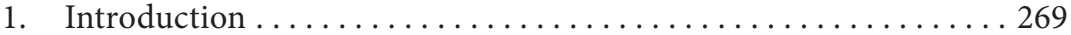

2. News Flows in Today's World: Digital Platforms and their

Role in Disseminating News and Information . . . . . . . . . 272

3. How the EU and its Member States React to the Spread of Fake News. . . . . . . . . . . . . . . . . . . . . . . . . . . 275

4. Social Media's Response to Fake News: Solutions Offered . . . . . . . 278

5. Filtering Systems and Constitutional Guarantees of Freedom of Expression and Information . . . . . . . . . . 280

5.1. The Legal Distinction between Value Judgements and False Information.................... 281

5.2. Social Media's Accountability in the Spread of Fake News . . . . . . . . . . . . . . . . . . . . . . . . 285

6. Conclusions.................................... 287

15. Fighting Online Disinformation: Did the EU Code of Practice Forget about Freedom of Expression?

Aleksandra Kuczerawy . . . . . . . . . . . . . . . . . . . . . . . . 291

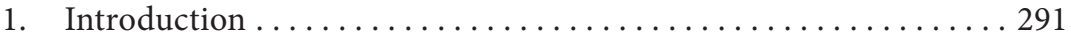

2. What is in the Code? ........................... 293

2.1. Scrutiny of Ad Placements . . . . . . . . . . . . . . . 293

2.2. Political Advertising and Issue-Based Advertising . . . . . . . 294

2.3. Integrity of Services. . . . . . . . . . . . . . . . . . . . . . 294

2.4. Empowering Consumers. . . . . . . . . . . . . . . . . 295

2.5. Empowering the Research Community .............. 296

2.6. Monitoring Effectiveness . . . . . . . . . . . . . . . . . . 296

3. Freedom of Expression Concerns. . . . . . . . . . . . . . . . 297

3.1. Principles of the Right to Freedom of Expression in Europe 
3.2. Restrictions on Lawful Speech..................... 299

3.3. Delegated Private Enforcement ................ 300

4. Possible Safeguards ............................ 303

4.1. Notification to the Content Provider. . . . . . . . . . . . . 303

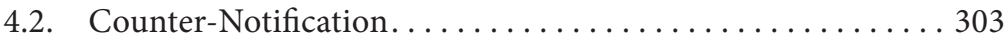

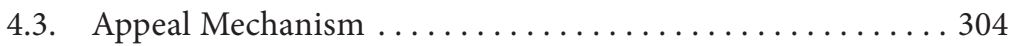

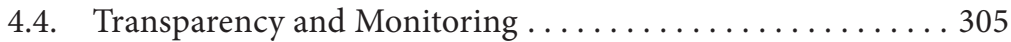

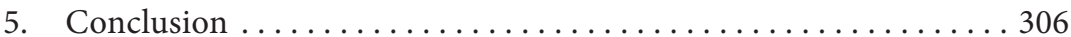

16. Regulating Internet Content with Technology: Analysis of Policy Initiatives Relevant to Illegal Content and Disinformation Online in the European Union

Trisha Meyer, Christopher T. Marsden and Ian Brown . . . . . . 309

1. Introduction . . . . . . . . . . . . . . . . . . . . . . . . . . . . 309

2. Illegal Content Online . . . . . . . . . . . . . . . . . . 313

3. Disinformation Online ...................... 318

4. Transparency in Technical Interventions $\ldots \ldots \ldots \ldots \ldots \ldots \ldots \ldots \ldots \ldots$

5. Conclusions. . . . . . . . . . . . . . . . . . . . . . . . . . . . . . . . 324

17. The War against Fake News in the Digital Age and the Weapons in Our Intellectual Arsenal

Stamos Archontis . . . . . . . . . . . . . . . . . . . . . . . 327

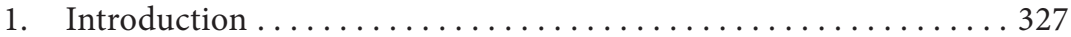

2. The Problems of Exaggerated Titles and Clickbaiting . . . . . . . 332

3. Assessing the Accuracy of Photos ................... 333

4. Investigating Sources . . . . . . . . . . . . . . . . . . . . 334

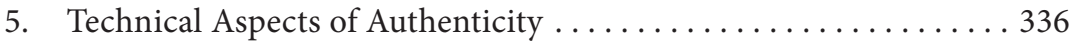

6. Closing Remarks ............................. 338

18. In the Name of Scientific Advancement: How to Assess

What Constitutes 'Scientific Research' in the GDPR to Protect

Data Subjects and Democracy

Heidi Beate Bentzen. . . . . . . . . . . . . . . . . . . . . . . . . . . . . . 341

1. Introduction . . . . . . . . . . . . . . . . . . . . . . 341

2. The Privileged Position of Scientific Research in the GDPR. . . . . . 344

2.1. Lawful Basis for Data Processing. . . . . . . . . . . . . 345

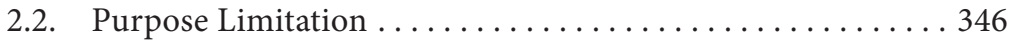

2.3. Storage Limitation . . . . . . . . . . . . . . . . . . . . . 346

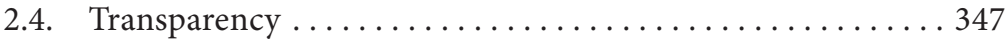


2.5. Data Subject Rights . . . . . . . . . . . . . . . . . . . . . 347

2.6. Third-Country Data Transfer................... 348

2.7. Code of Conduct . . . . . . . . . . . . . . . . . . . . . 348

3. What Constitutes Scientific Research?. . . . . . . . . . . . . . . . . . 348

3.1. The Term 'Scientific Research' within the Context of the GDPR. . . . . . . . . . . . . . . . . . . . . . . . 348

3.2. Potential Assessment Criteria. . . . . . . . . . . . . . . . . 349

3.2.1. The Role of the Legal Entity.............. 351

3.2.2. The Role of those Carrying Out the Activity...... . 353

3.2.3. Quality Standards Including Scientific Methodology and Scientific Publication .................. 355

3.2.4. Potential Assessment Criteria Based on Jurisprudence. . . . . . . . . . . . . . . . . . 361

4. De Lege Ferenda . . . . . . . . . . . . . . . . . . . . . . . . . . . . . . . . . 362

5. Concluding Remarks ......................... 364

19. Tackling Mis- and Disinformation in the Context of Scientific Uncertainty: The Ongoing Case of the COVID-19 'Infodemic' (Invited Contribution)

Mihalis Kritikos ............................. 367

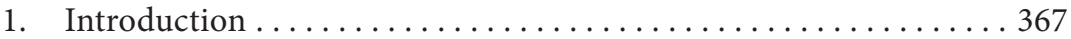

2. Outlining the Problem............................ 369

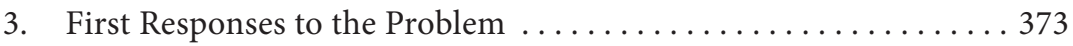

3.1. International Level: The World Health Organization . . . . . . 373

3.2. International Level: Social Media Platforms and Independent Fact-Checking Organisations. . . . . . . . 375

3.3. Supranational Level: The European Union. . . . . . . . . . . . . 377

3.4. Data-Sharing Initiatives $\ldots \ldots \ldots \ldots \ldots \ldots \ldots \ldots \ldots$

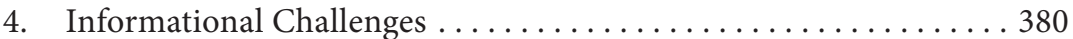

5. Concluding Remarks ....................... 383 


\section{LIST OF ABBREVIATIONS}

\begin{tabular}{|c|c|}
\hline AfD & Alternative für Deutschland (Germany) \\
\hline AFP & Agence France-Presse \\
\hline ANEL & 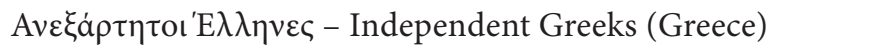 \\
\hline $\mathrm{BBC}$ & British Broadcasting Corporation \\
\hline CCTV & Closed Circuit Television \\
\hline $\mathrm{CDC}$ & Centre for Disease Control and Prevention (US) \\
\hline CFREU & Charter of Fundamental Rights of the European Union \\
\hline CIA & Central Intelligence Agency (US) \\
\hline CJEU & Court of Justice of the European Union \\
\hline CNN & Cable News Network (US) \\
\hline COVID-19 & Coronavirus disease 2019 \\
\hline DUP & Northern Ireland's Democratic Unionist Party \\
\hline EBU & European Broadcasting Union \\
\hline $\mathrm{EC}$ & European Commission \\
\hline ECB & European Central Bank \\
\hline ECDC & European Centre for Disease Prevention and Control \\
\hline ECFR & European Council of Foreign Relations \\
\hline ECHR & European Convention on Human Rights \\
\hline ECtHR & European Court of Human Rights \\
\hline EDPB & European Data Protection Board \\
\hline EDPS & European Data Protection Supervisor \\
\hline EEAS & European External Action Service \\
\hline $\mathrm{EP}$ & European Parliament \\
\hline EPI-WIN & Information Network for Epidemics \\
\hline ERT & 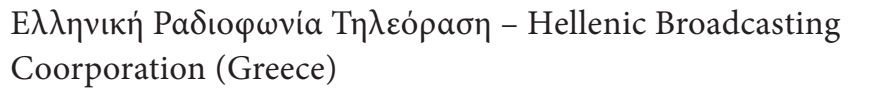 \\
\hline EU & European Union \\
\hline FCC & Federal Communications Commissions \\
\hline FM & Frequency Modulation \\
\hline FT & Financial Times \\
\hline FYROM & Former Yugoslav Republic of Macedonia (North Macedonia) \\
\hline GDPR & General Data Protection Regulation \\
\hline HLEG & $\begin{array}{l}\text { High-Level Expert Group on Fake News and Online } \\
\text { Disinformation }\end{array}$ \\
\hline
\end{tabular}


HR High Representative of the Union for Foreign Affairs and Security Policy

ICT Information and Communications Technologies

IFCN International Fact Checking Network

IMF International Monetary Fund

IRA Internet Research Agency (Russia)

ISIS Islamic State of Iraq and Syria

ISSPs Information Society Service Providers

IT Information Technology

KGB Komitet Gossoudarstvennoï Bezopasnosti - State Security

Committee (Russia)

LPPU Loyalist Peaceful Protest Updater

MLA Member of the Legislative Assembly

MP Member of the Parliament

MSM Mainstream Media

NATO North Atlantic Treaty Organization

NGO Non-Governmental Organisation

NHS National Health Service

NIO Northern Ireland Office

NPI National Policy Institute

OECD Organisation for Economic Co-operation and Development

Pegida Patriotische Europäer gegen die Islamisierung des Abendlandes Patriotic Europeans against the Islamisation of the West

PHEIC Public Health Emergency of International Concern

PIRA Provisional Irish Republican Army

PISA Program for International Student Assessment

PNAS Proceedings of the National Academy of Sciences of the USA

PSNI Police Service of Northern Ireland

RCCE Risk Communication and Community Engagement

SABAM Société d’Auteurs Belge - Belgische Auteurs Maatschappij -

Belgian Association of Authors, Composers and Publishers

SAS Special Air Services

SDLP Socialist Democratic and Labour Party (Northern Ireland)

SEEBRIG South-Eastern Europe Brigade

SEME Search Engine Manipulation Effect

SGP Staatkundig Gereformeerde Partij - Christian Reform Political Party (the Netherlands)

SOMA Social Observatory for Disinformation and Social Media Analysis

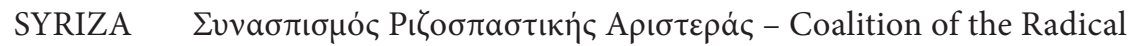
Left (Greece)

TEU Treaty on European Union

TFEU Treaty on the Functioning of the European Union 


$\begin{array}{ll}\text { UK } & \text { United Kingdom } \\ \text { UN } & \text { United Nations } \\ \text { UNESCO } & \text { United Nations Educational, Scientific, and Cultural Organization } \\ \text { US } & \text { United States } \\ \text { UUP } & \text { Ulster Unionist Party } \\ \text { UVF } & \text { Ulster Volunteer Force } \\ \text { VVD } & \text { Volkspartij voor Vrijheid en Democratie - Liberal Political Party } \\ & \text { (the Netherlands) } \\ \text { WDF } & \text { Wardle and Derakhshan Framework } \\ \text { WHO } & \text { World Health Organization }\end{array}$





\section{LIST OF CONTRIBUTORS}

Stamos Archontis

Ellinika Hoaxes, Greece

Daniel Barnhizer

College of Law, Michigan State University, United States

Anja Bechmann

School of Communication and Culture - Media Studies, Aarhus University, Denmark

Heidi Beate Bentzen

Centre for Medical Ethics and Norwegian Research Center for Computers and Law, University of Oslo, Norway

Ian Brown

Research ICT Africa, South Africa

Adam Candeub

College of Law, Michigan State University, United States

Michael S. Daubs

School of English, Film, Theatre and Media Studies, Victoria University of Wellington, New Zealand

Johan Farkas

School of Arts and Communication, Malmö University, Sweden

Monika Hanych

Faculty of Law, Masaryk University, Czech Republic

Rafał Klepka

Faculty of Social Sciences, Pedagogical University of Cracow, Poland

Dariusz Kloza

Research Group on Law, Science, Technology and Society (LSTS),

Vrije Universiteit Brussel (VUB), Belgium

Ioulia Konstantinou

Research Group on Law, Science, Technology and Society (LSTS),

Vrije Universiteit Brussel (VUB), Belgium 


\section{Mihalis Kritikos}

Scientific Foresight Unit (STOA), Directorate-General for Parliamentary

Research Services (EPRS), European Parliament, Belgium

\section{Aleksandra Kuczerawy}

Centre for IT and IP Law (CiTiP), KU Leuven, Belgium

\section{Elżbieta Kużelewska}

Centre for Direct Democracy Studies (CDDS), Faculty of Law, University of Białystok, Poland

Sid Lukkassen

Dr. Sid Consultancy, the Netherlands

Christopher T. Marsden

@SussCIGR Sussex Centre for Information Governance Research, University of Sussex, United Kingdom

Trisha Meyer

Brussels School of Governance (BSG) (an alliance between the Institute for European Studies and Vesalius College), Vrije Universiteit Brussel (VUB), Belgium

\section{Vagelis Papakonstantinou}

Research Group on Law, Science, Technology and Society (LSTS),

Vrije Universiteit Brussel (VUB), Belgium

\section{Cristina Pauner Chulvi}

Faculty of Legal and Economic Sciences, University Jaume I, Castellon, Spain

Tanja Pavleska

Laboratory for Open Systems and Networks, Jozef Stefan Institute (JSI),

Slovenia

Marek Pivoda

Faculty of Law, Masaryk University, Czech Republic

Paul Reilly

Information School, University of Sheffield, United Kingdom

Nelson Ribeiro

School of Human Sciences, Universidade Católica Portuguesa (UCP), Portugal

Jannick Schou

Independent researcher, Denmark

\section{Jamie Shea}

Brussels School of Governance (BSG) (an alliance between the Institute for European Studies and Vesalius College), Vrije Universiteit Brussel (VUB), Belgium 
Thanos Sitistas

Ellinika Hoaxes, Greece

Andrej Školkay

School of Communication and Media (SCM), Slovakia

Matteo Stocchetti

Department of Culture and Media, Arcada University of Applied Sciences,

Finland

Georgios Terzis

Brussels School of Governance (BSG) (an alliance between the Institute for European Studies and Vesalius College), Vrije Universiteit Brussel (VUB), Belgium

Daniel Trottier

Erasmus School of History, Culture and Communication; Department of Media and Communication, Erasmus Universiteit Rotterdam (EUR), the Netherlands

Ewelina Waśko-Owsiejczuk

Department of History and International Relations, University of Białystok, Poland

Bissera Zankova

Media 21 Foundation, Bulgaria 
